\title{
TEMETTUAT KAYITLARINA GÖRE ERMENAS (IRLAMAZ) KÖYÜ’NÜN SOSYO- EKONOMIKK DURUMU (1844-1845)
}

\section{ERMENAS (IRLAMAZ) VILLAGE'S SOCIO-ECONOMIC SITUATION ACCORDING TO TEMETTUAT REGISTERS (1844-1845)}

\author{
Zafer Atar* ìlker M. Çağlar**
}

\section{Özet}

Bu çalışmada, 1844-1845 yılında Aydın Vilayeti Saruhan Sancağı Turgutlu Kazası'na bağlı bir köy olan Ermenas'in (Irlamaz), 2762 numaralı temettuat defterinde yer alan kayıtlardan hareketle, 19. yüzyıl ortalarında sosyal ve ekonomik yapısının ortaya konulması amaçlanmıştır. Defterden yola çıkılarak, köy ahalisinin bu yıllarda geçimini tarım ve hayvancılıktan sağladığını söylemek mümkündür. Tarımsal ürünler olarak pamuk, üzüm, buğday, darı, zeytin ön plana çıkarken, büyükbaş olarak inek ve manda yetiştirildiği görülmektedir. İncelenen dönemde, Irlamaz Köyü'nde küçükbaş hayvancılık yapıldığı hususunda bir bilgi elde edilememiştir. Köydeki meslekler de, tarım ve hayvancılığa paralellik arz etmekte olup, erbâb-1 ziraat, rençber ve irgad en çok görülen mesleklerdir. Köylülerin "vergiyi mahsusa" nın yanında ödedikleri vergilerin başında da öşür gelmektedir. Bu çalışmada köylülerin verdikleri bu vergiler de ortaya konulmaya çalışılacaktır.

Anahtar Kelimeler: Manisa, Turgutlu, Irlamaz, Ermenas, Temettuat, Sosyal ve Ekonomik Hayat.

\section{Abstract}

This study aims at setting forth the social and economical structure of Ermenas (Irlamaz) Village of Turgutlu Town in Saruhan Sanjak of Aydın Province during mid 19th century making use of the Temettuat Defter dated 1844-1845 and numbered 2762. It is possible to infer from the registries that the villagers earned their livings from farming and animal husbandry in these years. While cotton, grapes, wheat, maize, olive were heading agricultural crops, cow and buffalo raising was common. We have found no information on raising sheep and goats in Irlamaz Village during the investigated period. Occupations in the village show parallelism to farming and animal husbandry and agricultural labour; farmhand and workman were the most common jobs. Tithe was in the lead addition to the Private Taxes that the villagers paid. In this study, these taxes will be presented as well.

Key Words: Manisa, Turgutlu, Irlamaz, Ermenas, Temettuat, Social and Economical Life.

\footnotetext{
*(Yrd.Doç.Dr.) Manisa Celal Bayar Üniversitesi, Fen-Edebiyat Fakültesi, Tarih Bölümü, atarzafer@hotmail.com **(Dr.) Milli Ĕ̆itim Bakanlı̆̆ı, magnisa45@hotmail.com
} 


\section{Giriş}

Çalışma konumuzun da temel dayanağını teşkil eden temettü' vergisinin Tanzimat'tan önce ilk ortaya çıkışı, ihtisap resmi şeklindedir. Temettü' Arapça kâr etmek anlamına gelmektedir. II. Mahmud zamanında söz konusu vergi "şehriye-i dekâkîn”, "yevmiye-i dekâkîn" adlarıyla anılan vergilerle bütün yiyecek, içecek, giyecek ve saireden muhtelif adlarla ve farklı tarifeler ile alınan vergilerden ibaretti (Pakalın, 2004: 453). Tanzimat ile beraber, birçok alanda olduğu gibi malî yapıda da bazı düzenlemeler yapılmış ve ayrı isimler altında toplanan vergilerin tek bir kaleme indirgenerek tahsis edilmesi amaçlanmıştır (Kütükoğlu, 1995: 395). Temettuat defterleri bilhassa 19. yüzyıl ortalarında Osmanlı taşrasının malî ve iktisadî durumunu sergilemesi bakımından önemli kaynaklardır. Bu defterlerde tahriri yapılan yerin, toplam arazi miktarını, ekili-dikili ve nadasa bırakılan toprakların kapsadığı alanı, yetiştirilen ziraî ürünlerin çeşitliliğini, miktarını ve bu ürünlerden elde edilen gelir ile dönüm başına düşen verimliliği görebilmekteyiz (Öztürk, 2000: 537-538).

Çalışmamıza esas olan defter, Başbakanlık Osmanlı Arşivi Maliye Nezareti Temettuat Defterleri tasnifinde yer alan 2762 numaralı defterdir. Defter 14 varak olup, sonradan sayfa numaraları verilmiştir. En son numaralandırılan sayfa 29 'dur. Defterin İzzeddin Köyü'ne ait hane bilgilerini içeren 11. sayfasından sonra, "Karye-i Ermenas tabi-i der liva-i Saruhan kaza-i Kasaba-i Turgutlu" başlığıyla Irlamaz'a dair kayıtlar başlamaktadır. Defterin kapak sayfasında ise "İzzeddin ve Ermenas Karyeleri Der-kaza-i Turgutlu" ibaresi yer almaktadır. İlk altı varak İzzeddin Köyü'ne ayrılmış, diğerleri ise bizim çalışma konumuzu teşkil eden, yine Turgutlu Kazası'na bağlı bir köy durumunda ve o zamanki ismi Ermenas olan, Irlamaz Köyü'ne aittir. Her bir sayfada 8-10 arasında haneye ait bilgiler yer almaktadır. Defterde kayıtlar "hane" ve "numara" verilerek tutulmuştur. Aynı hanede birden fazla vergi mükellefi içeren sadece bir kayıt vardır. Bu nedenle son hane 71 ve numara ise 72' dir (BOA., ML.VRD.TMT.d. 2762).

Irlamaz Köyü'nün tarihi ile ilgili elimizdeki ilk bilgi 1530 yılına aittir. Bu dönemde köyün ismi kayıtlarda Ormenos şeklinde geçmekte olup, Yengi Nahiyesi'ne bağlı bir köy durumundadır (Çağlar, 2014: 12). 1575 yılında köyde, 17 çiftlik ile sonradan padişah emriyle satılarak, bağlık hale getirilip, öşür ve rüsumat vermek şartıyla ahalinin kullanımına sunulan bir hassa çiftliği vardır. Ayrıca bu dönemde köyde, buğday, arpa, burçak, nohut, çavdar, susam, börülce, soğan, patlıcan, pamuk, armut, kestane ve üzüm mahsulü elde edilmekle beraber, koyun yetiştiriciliği de büyük öneme sahiptir. Köyün kışlak ve yaylak olmak üzere iki farklı mahallesi ve iki de değirmeni mevcuttur. 1703 yılında köyde bir derbent mevkii bulunması, buradan Bâd-ı hevâ vergilerinden, "resmi ulak" vergisinin tahsil edilmesi, köyün bir geçit mahallinde yer aldı̆̆ını düşündürmektedir. Köy halkı, 1531'de 10.072 akça, 1575 ise 10.200 akça gelire sahiptir. XVII. yüzyıla gelindiğinde ise köyün ticarî hayatı giderek artmıştır (Emecen, 1989: 210- 
211). Köyün ismini ele aldığımızda ise, zaman içerisinde köyün isminin değişerek, Ermenas şeklinde telaffuz edilmeye başlandı̆̆ını görmekteyiz (BOA., ML.VRD.TMT.d. 2762). Kesin bir bilgiye ulaşamasak da, muhtemelen Cumhuriyet'ten sonra ise Ermenas ismi de terk edilerek, köy Irlamaz adını almıştır. Günümüzde Irlamaz Köyü, Turgutlu'nun 4 km güneyinde, adını aldığı Irlamaz Çayı'nın hemen kıyısında bulunmaktadır. Eski adı Ormenos olan bu çayın isminde, zamanla meydana gelen telaffuz değişikliklerinin köyün adını da etkilediğini görmekteyiz.

Bugün Irlamaz Köyü'nde sadece duvarlarının bir kısmı ayakta kalmış bir kilise kalıntısı mevcuttur. 19. yüzyılda köyde gayrimüslim nüfusa ait bir bilgiye ulaşılamadığından, bu kilisenin çok geç tarihli olmadığı düşünülmektedir. Yine köyün hemen batı ucunda metrûk halde bir namazgâha rastlanılmaktadır. Namazgâhın yapılış tarihi hakkında bir malumata erişilemese de, taş yapısı ve kemerli mimari tarzından oldukça eski bir dönemde inşa edildiği izlenimi edinilmektedir. Köyde belli aralıklarla tadilâttan geçirildiği anlaşılan bir cami de bulunmaktadır. Caminin minaresinde yer alan kitabede, minarenin H.1320/M.1903 yılında, Pınar-zade Hacı Ahmed Ağa'nın zevcesi Aişe Molla tarafından yaptırıldığı yazmaktadır. Caminin haziresinde Pınaroğulları'na ait, vefat tarihleri H.1307/M.1890 ile H.1325/1908 yılları arasını kapsayan, taşları okunur durumda beş de mezar vardır. Cami minaresinin tesis tarihinden daha önceki seneleri içeren mezarlardan, caminin inşasının çok daha önceye dayandığını söyleyebiliriz. Ayrıca köyün hemen bitişiğinde, kuzey istikametindeki bir tepe üzerinde Kandiren Dede Türbesi ve bir mezarlık yer almaktadır. Türbe hem Alevî-Bektaşîler hem de Sünnîler için bir ziyaret ve niyaz mekânıdır. Burada her sene muharrem ayı vesilesiyle aşure günü yapılır. Bu etkinliğe köyde ve civarda yaşayan tüm Alevî ve Sünnîler davet edilir, bu durum ortak yaşayışın ve hoşgörünün güzel bir örneğini sergilemektedir. ${ }^{1}$

\section{A- Irlamaz Köyü'nün Sosyal Durumu \\ 1- Nüfus}

Irlamaz Köyü'nün tespit edilebilen en eski nüfusu 1531 yılına dayanmaktadır. Feridun Emecen'in verdiği bilgilere göre, 1531 yılında Irlamaz Köyü'ndeki hane sayısı 66'dır. 4 hane de Karaca Yörüğü yaşamakta olup, toplam 70 haneden meydana gelmektedir. Her hanede 5 kişinin yaşadığı varsayılarak yapilan hesaplama ile köyün bu tarihteki nüfusu 350 olarak tespit edilmiştir (Barkan 1953: 11) 1575 yılında ise köyde 102 hane ve 136 mücerred ile birlikte nüfusu 650 civarına ulaşmıştır (Emecen, 1989: 210). 1842 yılına ait nüfus sayımında köyde 63 hane ve 133 erkek bulunmaktadır (BOA, Nfs.d. 2894: 1-7). Tüm toplumlarda kadın ve erkek miktarının genel itibariyle eşit dağılım gösterdiği düşünüldü̆̆ünde, 1842 yılı için yaklaşık olarak köyde 266 kişi yaşadığını söyleyebiliriz.

\footnotetext{
1 Ağırlıklı olarak arşiv ve saha araştırmasıyla, konuyla ilgili yayınları da içeren bu çalışmamızda, köy kültürüne ait yerel bilgiler muhtelif zamanlarda Irlamaz halkıyla yapılan mülâkatlardan elde edilmiştir. Bu konuda köy muhtarı Ali Akman bize çok yardımcı olmuştur.

2 Ömer Lütfi Barkan klasik dönemde Osmanlı Devleti'nin nüfusunu tespit edebilmek için, tahrir defterlerindeki hane sayılarının beş ile çarpılması uygulamasını ileri sürmüştür. Bkz. Aynı yer.
} 
Yine bu yıla ilişkin hane sayısı ve tahminî nüfustan hareketle, hane başına (erkek nüfus $\mathrm{x}$ 2 / hane sayısı) ortalama 4 kişi düşmektedir. 1844 tarihli Ermenas (Irlamaz) Temettuat Defteri'nde 71 hane kayıtlıdır. Bu noktada hane sayısını 5 ile çarpmak yerine, 1842 yılı nüfus verilerinde elde ettiğimiz hane başına düşen kişi sayısı olan 4 ile çarpmanın daha sağlıklı bir veri sunacağını düşünmekteyiz. Bu durumda 1844 yılında tahminen Irlamaz Köyü'nde 284 kişi yaşamaktadır. 1891 yılına gelindiğinde ise Irlamaz, Kasaba (Turgutlu) Kazası'nın nüfus bakımından en kalabalık köyü durumundadır. Bu tarihte köy 115 haneden müteşekkil olup, nüfusu 564 kişidir (Aydın Vilayet Salnamesi, 1308: 479). ${ }^{3}$

19. yüzyıl dâhilinde Irlamaz'da gayrimüslim nüfusa dair bir bilgiye ulaşılamamıştır. Fakat Irlamaz ahalisi ile yapılan görüşmelerden çıkan intiba ile bugün sadece duvarlarının bir kısmı ayakta kalmış bir kilisenin köydeki varlığı, 1920'lerin başına kadar Irlamaz'da az sayıda da olsa, Rum'un yaşadığını göstermektedir. Rumların Anadolu'ya ve bilhassa batı bölgelerine gelmesi, 1770 Mora İsyanı neticesinde gerçekleşmiştir. Mora Yarımadası'ndaki isyanın bastırılmasıyla, buradan firar eden Rumlar, başta Ege Bölgesi olmak üzere Anadolu'ya yerleşmişlerdir (Nakracas, 2005: 58). Muhtemelen Irlamaz'a da, bu süreç zarfını takiben 1850'lerden sonra bir Rum iskânı meydana gelmiştir.

Tablo-1: Y1llar İçerisinde Irlamaz Köyü'nün Nüfusu

\begin{tabular}{|c|c|c|}
\hline Yıllar & Hane ayısı & Tahmini Nüfus \\
\hline 1531 & 70 & 350 \\
\hline 1575 & 102 & 510 \\
\hline 1842 & 63 & 266 \\
\hline 1844 & 71 & 284 \\
\hline 1891 & 115 & 564 \\
\hline
\end{tabular}

\section{2- Lakaplar ve Sülale Adları}

Kişileri diğer insanlardan ayıran en önemli özelliklerinden biri, sahip olduğu adıdır. Temettuat defterlerinde kişilerin adları, bazen sülale isimleri ile birlikte, bazen babalarının adlarıyla, bazen de bunların yerine kişinin sıfatı veya lakabıyla beraber belirtilmiştir. ${ }^{4} \mathrm{Bu}$ bilgiler, köyün sosyal, dini ve etnik yapısını ortaya çıkarmak için önemlidir.

\footnotetext{
${ }^{3}$ Bu tarihte Turgutlu'nun Ermenas'tan (Irlamaz) başka, 11 köyü daha bulunmaktadır. Bkz. Aynı yer.

${ }^{4}$ Irlamaz Köyü'nde yaşayan, 71 hane reisinden 59 hane reisinin ismi sülale ismiyle, 4'ü babasının ismi ile birlikte, $8^{\prime}$ inin adı ise sadece kendi isimleri ile verilmiştir.
} 


\section{a) Şahsi Lakaplar}

1844 Yilı Irlamaz Köyü'ne ait temettuat defterlerinde kimi hane reislerinin isimlerinin önünde bir takım lakaplar verilmiştir. Bu lakaplar; kişilerin yakın zamanda geldikleri memleketleriyle, dış görünüşleriyle ya da meslekleri ile alakalı olabiliyordu. Kişinin geldiği yerle ilgili, "Parsalı", "Sakızlı", "Kızılcalı"; fizikî yapısına dair, "Kara”, "Köse”, "Topal", "Zenci", meslekî durumunu belirten ise "Çulha", "Hallac" ve "Kiremitçi gibi lakapları defterde görebilmekteyiz. Ayrıca bu tasniflemenin dişında, "Hacı" lakaplı bir hane reisi de kayıtlarda geçmektedir. Bu lakaplardan "Zenci" defterde 2 defa, onun haricindekiler ise bir kez yer almaktadir.

Tablo-2: Irlamaz Köyü'ndeki Şahsi Lakaplar

\begin{tabular}{|l|c|}
\hline \multicolumn{1}{|c|}{ Lakap } & Kullanılma Sayısı \\
\hline Parsalı & 1 \\
\hline Çulha & 1 \\
\hline Hacı & 1 \\
\hline Hallac & 1 \\
\hline Kara & 1 \\
\hline Kızılcalı & 1 \\
\hline Kiremitçi & 1 \\
\hline Köse & 1 \\
\hline Sakılıl & 1 \\
\hline Topal & 1 \\
\hline Zenci & 2 \\
\hline
\end{tabular}

\section{b) Sülale Adları}

Defterdeki hane reislerinin kayıt formatları hep aynı şekilde değildir. Kimi hane reisleri sülale isimleri ile birlikte yazılmıştır. Sülalesi verilen hane reisi sayısı 59 olup, toplam haneye oranı \% 83,10'dur. Bazı hane reisleri ise sülaleleri belirtilmeden, babalarının ismi verilerek, Arapça'da "oğlu” anlamına gelen "bin” kelimesi ile kaydedilmiştir. Bu şekilde ifade edilen hane reisi sayısı 4 olup, toplam haneye oranı \% 5,63'tür. Herhangi bir sülale adı ve babasının ismi eklenmeden sadece lakap olarak kaydedilen hane sayısı ise 8'dir. Bunların genele oranı da \% 11,27'dir.

Tablo-3: Hane Reislerinin Temettuat Defterlerindeki Kayıt Şekilleri ve Oranları

\begin{tabular}{|l|c|l|}
\hline Hane Reislerinin Kayıt Şekli & Hane Sayısı & \multicolumn{1}{|c|}{ Oranı } \\
\hline Sülale İsmi ile Birlikte Verilen & 59 & 83,1 \\
\hline Babasının İsmi ile Birlikte Verilen & 4 & 5,63 \\
\hline Sadece İsim Olarak Yer Alan & 8 & 11,27 \\
\hline Toplam & 71 & \\
\hline
\end{tabular}


Sülale ismi verilerek kaydedilen hane reislerinin sayısı 59'dur. Bazı sülaleler birden fazla haneye ait olup, defterde toplam 40 farklı sülale yer almaktadır. Aynı sülale ismine sahip üçten fazla hane reisi bulunmamaktadır.

Tablo-4: Irlamaz Köyü Temettuat Defteri'ne Göre Sülale Adları

\begin{tabular}{|l|l|l|l|l|c|}
\hline $\begin{array}{l}\text { Sira } \\
\text { No }\end{array}$ & Sülale İsmi & $\begin{array}{l}\text { Kullanılma } \\
\text { Sayısı }\end{array}$ & $\begin{array}{l}\text { Sıra } \\
\text { No }\end{array}$ & Sülale İsmi & $\begin{array}{l}\text { Kullanılma } \\
\text { Sayısı }\end{array}$ \\
\hline 1 & Abdülcü Oğlu & 1 & 21 & Hızır Oğlu & 1 \\
\hline 2 & Akkız Oğlu & 1 & 22 & İzzeddinli Oğlu & 1 \\
\hline 3 & Arı Oğlu & 2 & 23 & Kabacalı Oğlu & 1 \\
\hline 4 & Ayan Oğlu & 1 & 24 & Kara Ahmet Oğlu & 3 \\
\hline 5 & Ayvaz Oğlu & 2 & 25 & Keleş Oğlu & 1 \\
\hline 6 & Benyar Oğlu & 1 & 26 & Kırbaş Oğlu & 2 \\
\hline 7 & Çelik Oğlu & 2 & 27 & Koca Halil Oğlu & 1 \\
\hline 8 & Çulha Murad & 1 & 28 & Koca Osman Oğlu & 1 \\
\hline 9 & Dalveli Oğlu & 1 & 29 & Kuru Oğlu & 2 \\
\hline 10 & Davud Oğlu & 1 & 30 & Mahmud Oğlu & 1 \\
\hline 11 & Demirci Oğlu & 1 & 31 & Menemenli Oğlu & 1 \\
\hline 12 & Gedüslü Murad Oğlu & 1 & 32 & Muhtar Oğlu & 1 \\
\hline 13 & Güme Oğlu & 1 & 33 & Murad Oğlu & 1 \\
\hline 14 & Hacı Ahmed Oğlu & 1 & 34 & Müslim Oğlu & 1 \\
\hline 15 & Hacı Ali Oğlu & 1 & 35 & Sancaktar Oğlu & 1 \\
\hline 16 & Hacı İlyas Oğlu & 1 & 36 & Sandal Oğlu & 3 \\
\hline 17 & Hacı Mahmud Oğlu & 3 & 37 & Sarı Mahmud Oğlu & 1 \\
\hline 18 & Hallac Oğlu & 3 & 38 & Sarı Mehmed Oğlu & 1 \\
\hline 19 & Hamza Oğlu & 3 & 39 & Tekeli Oğlu & 2 \\
\hline 20 & Hasan Arab Oğlu & 1 & 40 & Topaç Oğlu & 1 \\
\hline
\end{tabular}

Buradaki sülale adlarının veriliş biçimleri değerlendirmeye tabi tutulduğu zaman, bazılarının "Gedüslü Oğlu”, “Menemenli Oğlu”, “Tekeli Oğlu” ve "İzzeddinli Oğlu” örneklerindeki gibi, yer adlarından esinlenerek zuhur ettiği düşünülebilir. Bu kişilerin, önceki yıllarda bu yerlerden gelip Irlamaz Köyü'ne yerleştiği veya bir müddet buralarda kalmış oldukları anlaşılabilir. Kimi sülale isimlerinin ise, bir meslekten kaynaklandı̆̆ı görülmektedir. Bunlar, "Çulha”, "Demirci", "Hallac" gibi meslekî ifadelerdir. Kişilerin dış görünüşü veya fizikî durumları da yine sülale adları için dayanak teşkil etmiştir. "Çelik Oğlu”, “Kırbaş Oğlu”, “Kuru Oğlu” ve “Topaç Oğlu” bu kapsamda değerlendirilebilir.

Irlamaz Temettuat Defteri'nde, "Davud Oğlu", "Mahmud Oğlu" gibi kişi ismi esash sülale adlarının çokça yer aldığı görülmektedir. Ayrıca "Hacı Ahmed Oğlu”, "Sarı 
Mahmud Oğlu" ve "Koca Osman Oğlu" şeklinde hane reislerinin sadece bir sifatla belirtilerek, yazıldığı da olmuştur. Sülale isimlerinin bazıları ise, kişilerin geçmiş yıllarda yaptıkları görevleri yansıtmaktadır. "Muhtar Oğlu" ve "Sancaktar Oğlu" bu tip sülale isimlerine örnek verilebilir. Bunların yanında, "Abdülcü Oğlu”, "Akkız Oğlu”, "Ayan Oğlu", "Benyar Oğlu", "Güme Oğlu" ve "Sandal Oğlu" gibi belirli bir tasnife tâbi tutamadığımız sülale isimleri de kayıtlarda mevcuttur.

Irlamaz Köyü'nde Kandiren Dede Türbesi etrafında, Irlamaz Camii haziresinde ve köy mezarlığında bulunan, bize öncelikle sülale isimleri konusunda kaynaklık edebileceğini düşündüğümüz bazı mezar taşlarında geçen şahıs ve sülale adlarıyla, ölüm tarihlerini bir tablo üzerinde göstermeyi uygun bulduk. Sözü geçen yerlerde Osmanlı dönemine ilişkin taşı okunabilen toplam 114 kabir mevcuttur. Bu taşlar içerisinde tarihi tespit edilebilen en eski mezar H.1200/M.1786 tarihlidir. Hem Kandiren Dede Türbesi civarındaki mezarlıkta, hem de köy mezarlığında Kocaoğlu, Davazlığlu ve Menemenlioğlu gibi aynı sülalelere mensup kişilere ait kabirler bulunmaktadır (Tepekaya, 2008: 190).

Tablo-5: Irlamaz Köyü Mezar Taşlarındaki Bazı Şahıs Adları ve Ölüm Tarihleri5

\begin{tabular}{|c|c|c|}
\hline Sira No & İsimler & Ölüm tarihleri ( H/ M) \\
\hline 1 & Dolma Halil'in Oğlu Ahmed & $1211-1797$ \\
\hline 2 & Mirteza Kız1 Hatice & $1214-1800$ \\
\hline 3 & Hacı Çakır Oğlu Sadık & $1215-1801$ \\
\hline 4 & Tavazlı Oğlu Halil & $1215-1801$ \\
\hline 5 & Uzun Hamza Oğlu Ali & $1216-1802$ \\
\hline 6 & Bacak Hacı Mehmed & $1219-1805$ \\
\hline 7 & Arı Oğlu Hasan & $1221-1807$ \\
\hline 8 & Dalıncı Oğlu Muhammed & $1222-1808$ \\
\hline 9 & Sarı Mehmed & $1225-1811$ \\
\hline 10 & Davazlı Oğlu Mehmed Bayraktar & $1226-1812$ \\
\hline 11 & Pınar Oğlu Halil & $1230-1816$ \\
\hline 12 & Davud Oğlu Ahmed Kızı Cennet & $1232-1818$ \\
\hline 13 & Yaman Oğlu Bekir & $1240-1826$ \\
\hline 14 & Girdamlı Oğlu Hüseyin & $1243-1829$ \\
\hline 15 & Kadiri Oğlu Mehmed & $1246-1832$ \\
\hline 16 & Kangal Oğlu Hasan Kızı Ümmühan & $1248-1834$ \\
\hline 17 & Karcı Oğlu Süleyman & $1252-1838$ \\
\hline 18 & Ayvaz Oğlu Mustafa & $1255-1841$ \\
\hline 19 & Koca Osman Oğlu Kerimesi Fatıma & $1266-1852$ \\
\hline 20 & Murad Oğlu İbrahim Zevcesi Cennet & $1270-1856$ \\
\hline 21 & Menemenli Mustafa & $1271-1857$ \\
\hline
\end{tabular}

${ }^{5}$ Bu bilgiler Muzaffer Tepekaya'nın Osmanlı Dönemi Turgutlu Kitabeleri isimli eserinden elde edilmiştir. Bkz. Tepekaya, a.g.e., ss.191-298. 
TEMETTUAT KAYITLARINA GÖRE ERMENAS (IRLAMAZ) KÖYÜ’NÜN SOSYOEKONOMIK DURUMU (1844-1845)

\begin{tabular}{|l|l|c|}
\hline 22 & Müslim Oğlu Hüseyin Zevcesi & $1278-1864$ \\
\hline 23 & Sandal Oğlu İbrahim Zevcesi Fatıma & $1278-1864$ \\
\hline 24 & Çalık Oğlu Zevcesi Ümmühan & $1280-1866$ \\
\hline 25 & Hamza Oğlu Ali & $1281-1867$ \\
\hline 26 & Kara Oğlu Hacı Mustafa & $1285-1871$ \\
\hline
\end{tabular}

\section{Mesleki Yapılanma}

Irlamaz Köyü'nün iktisadî yapısını belirleyen temel unsur tarım faaliyetleridir. Erbab-1 ziraatı, rençberliği ve irgatlığı bu kapsama alabiliriz. Irlamaz Temettuat Defteri'nde mezru arazi toplamına göre, mesleği erbab-1 ziraat olarak kayıtlı hane reislerine kişi başına 37 dönüm, rençber şeklinde geçenlere 14 dönüm ve irgat ifadesiyle yazılanlara ise 4 dönüm tarım arazisi düşmektedir. Bu haliyle defterde, büyük toprak malikleri ve yüksek gelir sahiplerinin meslekleri erbab-1 ziraat olarak belirtilmiştir. Rençber, tarım sektöründe ya da yapı işlerinde çalışan işçi (Sami, 2004: 671), ırgad ise yine tarım sektörü başta olmak üzere diğer işlerde de çalışan işçi anlamına gelmektedir (Sami, 2004: 90). Fakat Irlamaz dâhil olmak üzere Turgutlu ve yakın çevresinde "Rençber" kelimesi, "Leşber" şeklinde söylenmekle beraber, anlam olarak da, kendi tarım arazisi üzerinde ziraat yapan küçük ve orta ölçekli çiftçileri nitelemektedir. Yine Turgutlu havalisinde, "Irgad" tarla ve bahçe işlerinde belli bir ücret mukabilinde çalışan kişileri ifade etmekle birlikte, ırgadlık daha çok yıl boyunca aynı tarım arazisinde görev alıp toprağın bakımını üstlenen ve o mülk sahibine tâbi olan kişilerin ifâ ettiği bir vazifedir. ${ }^{6}$

Tablo-6: 1844 Yılında Irlamaz Köyü'ndeki Meslekler ve Oranları

\begin{tabular}{|l|c|c|}
\hline Meslek İsmi & Sayısı & Oranı (\%) \\
\hline Alil-Hastalıklı & 1 & 1,5 \\
\hline Ameleci & 12 & 16,5 \\
\hline Asakir-i Nizamiyede & 1 & 1,5 \\
\hline Çulha esnafından & 1 & 1,5 \\
\hline Erbab-1 ziraat & 20 & 28 \\
\hline Fukara Zümresi & 1 & 1,5 \\
\hline Irgat & 2 & 3 \\
\hline İmam & 1 & 1,5 \\
\hline
\end{tabular}

${ }^{6}$ Mevcut bilgiler, 12.12.2014 tarihinde çalışma sahamız dâhilinde, dedelerinden bu yana çiftçilikle uğraşmış bir aileye mensup olan Hasan Üstündağ ile yaptığımız görüşmede, rençber ve ırgad arasındaki farka dair edindiğimiz malumat üzerinedir. 


\begin{tabular}{|l|l|l|} 
Kahveci taifesinden & 1 & 1,5 \\
\hline Muhtar-Erbabı Ziraat & 1 & 1,5 \\
\hline Rençberan & 25 & 35 \\
\hline Boş & 5 & 7 \\
\hline Toplam & $\mathbf{7 1}$ & $\mathbf{1 0 0}$ \\
\hline
\end{tabular}

Irlamaz'da bu dönem içerisinde icra edilen işkollarının yüzdelik dağılımı ve sayısı şu şekildedir: En fazla görülen meslek \% 35'lik bir pay içeren rençberlik olup, toplam 25 hane reisini ifade etmektedir. Rençberliği \% 31'lik oran ve 21 hane reisi ile erbab-1 ziraat takip etmektedir. Defterde \% 3'lük nispete sahip ırgat şeklinde kayıtlı 2 kişi bulunmaktadır. Ayrıca mesleği ameleci olarak geçen \% 16,5'luk değere tekabül eden 12 hane reisini de, toprağa dayalı işçilik faaliyetinde bulunabileceklerini düşünerek tarım sektörüne dâhil edebiliriz. Kayıtlarda amelecilik kazanç getiren bir iş olarak addedilmiş ve "amelecilikten temettuatı" ifadesiyle kişinin geliri yazılmıştır. ${ }^{7}$ Tüm bu meslek gruplarını değerlendirmeye tâbi tuttuğumuz zaman, Irlamaz Köyü'nde 1844 yılında hane reislerinin yaklaşık \% 85'inin ziraatla meşgul olduğunu söylemek mümkündür. Bunlardan başka köyde, 1 imam, 1 kahveci ve 1 çulha esnafı da bulunmaktadır.

Irlamaz Temettuat Defteri'nde herhangi bir meslekî zümreye dâhil edemeyeceğimiz şekilde kayıtlı hane reisleri de mevcuttur. Bunlardan 1 hane reisi "alil" yani hastalıklı, 1 hane reisi asakir-i nizamiyede ve yine 1 hane reisi fukara zümresinden olarak kaydedilmiştir. 6 hane reisinin ise meslekleri belirtilmemiştir. Bu şekilde ifade edilenlerin tümü de kadındır.

\section{B- Irlamaz Köyü'nün Ekonomik Yapısı \\ 1- Hayvancilık}

Osmanlı Devleti'nin iktisadî yapısının temelini üretim ve emeğe dayalı küçük ölçekli sınâ̂ faaliyetleri oluşturmaktaydı. Geleneksel tarım toplumu özelliği sergileyen Osmanlı Devleti'nde her bölge ve hatta her şehir ayrı bir ekonomik birim niteliğinde kendi kendine yetmeye çalışıyordu (Mardin, 1995: 213). Bizim çalışma konumuza kaynaklık eden Irlamaz gibi kırsal kesim kapsamında kabul edebileceğimiz yerleşimlerde tarım ve hayvancılık temelli bir ekonomik hayat teşekkül etmiştir. Temettuat defterleri işte bu yapının ortaya çıkarılması ve değerlendirilmesi için fevkalâde değerlidir.

1844 yılında Irlamaz Köyü’nde hem sütünden, hem de nakliye ve yük taşımacılığ1 gibi gücünden istifade edilen büyükbaş hayvanlar bulunduğu görülmektedir. Bu hayvan gruplarından sadece sütünden yararlanılanlardan, gelir getirdiğinden hareketle temettu kaydedilmiştir. Diğerleri için böyle bir durum söz konusu değildir.

${ }^{7}$ BOA, M.L. VRD. TMT.d. 2762, s.28 hane no:66. 
TEMETTUAT KAYITLARINA GÖRE ERMENAS (IRLAMAZ) KÖYÜ’NÜN SOSYOEKONOMIK DURUMU (1844-1845)

Tablo-7: Irlamaz Köyü'ndeki Hayvan Grupları ve Bunların Oranları

\begin{tabular}{|l|c|l|}
\hline Hayvan Grubu & Sayısı & Oranı (\%) \\
\hline Büyükbaş Hayvan & 97 & 41,27 \\
\hline Yük ve Binek Hayvanı & 138 & 58,73 \\
\hline Toplam & $\mathbf{2 3 5}$ & $\mathbf{1 0 0}$ \\
\hline Arı Kovanı & 40 & \\
\hline
\end{tabular}

Irlamaz Köyü'ndeki 1844 yılı hayvancılık faaliyetlerine baktığımız zaman, büyükbaş hayvancılık, yük ve binek hayvancılığı ile arıcılığın yapıldığını görmekteyiz. Irlamaz Köyü etrafı küçük tepeciklerle çevrili bir vadi üzerine kurulmuştur. Köyün doğusuna gidildikçe ise yükselti artmakta ve $3 \mathrm{~km}$ kadar sonra arazi yayla yapısını almaktadır. Bu haliyle küçükbaş hayvan yetiştiriciliğine de müsait olan köyde hali hazırda bünyesinde 20'nin üzerinde keçi ve koyun barındıran üç tane sürü bulunmaktadır. Irlamaz ahalisi ile yapılan görüşmeler neticesinde köyde geçmişten bu yana azalmakla beraber, bilhassa küçükbaş hayvancılığın halkın geçim kaynakları içerisinde yer aldığı anlaşılmaktadır. Bugün köyde mevcut olan eski evlerin hemen hepsinin avlusunda bir damin da olması bu durumu desteklemektedir. Fakat 1844 yılını içeren Irlamaz Temettuat Defteri'nde, köy ahalisine ait hiçbir hanede, küçükbaş hayvan yetiştiriciliğine dair bir kayıt bulunmaması dikkat çekmektedir. Aynı durum Turgutlu'nun o dönemde diğer bir köyü olan İzzeddin için de geçerlidir. ${ }^{8}$ Hatta yine bu tarihte tahminen 9.000 civarında nüfus barındıran Turgutlu'da da temettuat defterlerine göre kayıtlı 1977 haneden, sadece 4 hane tarafından toplam 250 sağman koyun yetiştirilmekte olup, keçi besleyen hane görülmemektedir (Çağlar, 2014: 163).

Büyükbaş hayvan sınıfına dâhil ettiğimiz sağman manda, sağman inek ve bunların danaları ile düvelerinin toplamı 99 olup, tüm hayvan grupları içerisindeki oranı \% 41'dir. Ortalama hane başına bir veya iki tane büyükbaş hayvan düşmektedir. Yük ve binek hayvanı olarak değerlendirdiğimiz hayvan grubu ise öküz, katır, beygir, kısrak, tay ve merkeptir. Bunların sayısı 138 ve toplam hayvan miktarı içerisindeki paylarıysa \% 59'dur. Bu dönemde köyde arcılık faaliyetinde bulunan tek bir hane reisi vardır. Bu kişi 40 kovana sahip olup, arıcılıktan kazancı 320 kuruş olarak kaydedilmiştir. ${ }^{9}$

\section{a) Büyükbaş Hayvancılık}

Büyükbaş hayvan grubuna dâhil ettiğimiz hayvan sayısının toplamı 99'dur. Bunların 24'ü sağman manda, 20'si manda düğesi, 20'si sağman inek, 33'ü inek düğesi ve 2 tanesi de tosunla danadır. En az bir sağman mandaya sahip olan hane adedi 20'dir. Hane başına

${ }^{8}$ BOA, M.L. VRD. TMT.d. 2762, ss.1-11.

${ }^{9}$ BOA, M.L. VRD. TMT.d. 2762, s.21 hane no:22. 
düşen sağman manda sayısı 1,2 ve toplam büyükbaş hayvan sayısına göre oranı ise \% $24^{\prime}$ tür. Manda düğesinin sayısıysa 20'dir. En az bir manda düğesine sahip olan hane sayısı ise 14 'tür. Bunların hane başına düşen ortalaması 1,4 olup, aynı zamanda bu hane başına düşen en yüksek hayvan miktarıdır. Manda düğelerinin toplam büyükbaş hayvan sayısı içerisindeki payı ise \% 20'dir. Sağman manda ile manda düğesini beraber değerlendirdiğimiz zaman manda sayısının toplam hayvan sayısına göre oranının \% 45'in üzerinde olduğu görülür. Yani köydeki hayvanların yarısına yakını manda grubuna girmektedir. Mandanın sulak alanlara özgü bir hayvan olması ve köyün çay kıyısı kenarında kurulu bulunması, bu durumu izah etmek için yeterlidir.

Tablo-8: Irlamaz Köyü Temettuat Defterine Göre Büyükbaş Hayvancılık

\begin{tabular}{|l|l|l|l|l|}
\hline Hayvan Cinsi & $\begin{array}{l}\text { Hayvan } \\
\text { Sayısı }\end{array}$ & $\begin{array}{l}\text { Sahip Olan } \\
\text { Hane Sayısı }\end{array}$ & $\begin{array}{l}\text { Hane } \\
\text { Başına } \\
\text { Ortalama }\end{array}$ & $\begin{array}{l}\text { Toplam } \\
\text { Büyükbaş } \\
\text { Hayvanlara Oranı } \\
\mathbf{( \% )}\end{array}$ \\
\hline Sağman Manda & 24 & 20 & 1,2 & 24 \\
\hline Manda Düğesi & 20 & 14 & 1,4 & 20 \\
\hline Sağman İnek & 20 & 19 & 1,04 & 20 \\
\hline İnek Düğesi & 33 & 25 & 1,3 & 34 \\
\hline Tosun/dana & 2 & 2 & 1 & 3 \\
\hline \multicolumn{1}{|c|}{ TOPLAM } & $\mathbf{9 9}$ & - & - & $\mathbf{1 0 0}$ \\
\hline
\end{tabular}

Sağman inek sayısı ise 20'dir. En az bir sağman ineğe sahip hane sayısı 19 olup, hane başına düşen ortalama sağman inek sayısı takrîben 1'dir. Sağman ineklerin toplam büyükbaş hayvanlara oranı ise \% 20'dir. İnek düğesinin sayısıysa 33'tür. Büyükbaş hayvan sayısı bakımından en fazla adedi içermektedir. En az bir inek düğesine sahip hane sayısı ise 25'dir. Hane başına düşen ortalama inek düğesi sayısı, 1,3 olup, toplam büyükbaş hayvan grubu dâhilindeki payıysa \% 20'dir. Bu durumda Irlamaz Köyü'nde yaklaşık olarak her üç büyükbaş hayvandan birisi inek düğesidir. Tosun ve dana bu grupta yer alan en az sayıdaki hayvandır. Köyde 2 hanede toplam 2 tosun ve dana bulunmaktadır. Bunların büyükbaş hayvan grupları içindeki nispeti ise $\% 2$ 'dir.

Tablo-9: Irlamaz Köyü Temettuat Defterine Göre Büyükbaş Hayvan Sahiplik Oranı

\begin{tabular}{|l|c|c|}
\hline \multicolumn{1}{|c|}{ Hayvan Cinsi } & $\begin{array}{c}\text { Sahip Olan } \\
\text { Hane Sayısı }\end{array}$ & $\begin{array}{c}\text { Toplam Hane Sayısına } \\
\text { Oranı (\%) }\end{array}$ \\
\hline Sağman Manda & 20 & 27,7 \\
\hline Manda Düğesi & 14 & 19,4 \\
\hline Sağman İnek & 19 & 26,3 \\
\hline İnek Düğesi & 25 & 37,7 \\
\hline Tosun/dana & 2 & 2,7 \\
\hline
\end{tabular}


Yukarıdaki tabloda Irlamaz Köyü hane reislerinin büyükbaş hayvana sahip olma durumları ele alınmıştır. Toplam 72 hanenin 19'u sağman inek ve inek düvesi vardır. Buna göre Irlamaz Köyü'nde yaşayan hanelerin \% 26,3'ünün en az bir sağman ineği ve düvesi mevcuttur. Sağman manda sayısıysa 20 olup, bunun oranı ise \%27,7'dir. 14 hane de manda düvesi bulunup, bunların toplam hane sayısı içerisindeki payı ise \% 19,4'tür. Tosun ve Danaya sahip olan hane sayısı 2' dir. Bunların oranı ise $\% 2,7^{\prime}$ dir.

b) Yük ve Binek Hayvanları

Yük ve binek hayvanları grubuna öküz, katır, beygir, kısrak, tay ve merkeb dâhil edilmiştir. Henüz sanayinin gelişmediği, makineleşmenin başlamadı̆̆ı dönemlerde, tarımsal faaliyetler için hayvan gücü vazgeçilmez unsurların başında gelmektedir. Söz konusu toplumlarda, koşum ve taşımacılık amacıyla kullanılan bu hayvanlar, birikmiş bir servet niteliği de taşımaktadır (Güran, 1987: 258). Bunlar içerisinde özellikle öküz, temel geçim kaynaklarının başında ziraat gelen toplumlarda, büyük önem arz etmektedir. Çünkü ekimden önce arazinin sürülmesi, mahsulün taşınması gibi ziraî hayatın bütün safhalarında öküz önemli bir yer tutmaktadır. Zirai üretimin temel aracı sayılan öküzün, hane başına bir çift olması halinde, tarımsal üretim amacıyla kullanılması mümkündür. Nitekim Osmanlı Devleti'nde ziraî rejimin ana ünitesi olarak kabul edilen "çift-hanesi" terimi ile "1 çift öküz ile işleyebileceği toprağa sahip olan hane" ifade edilmektedir. Bir çift öküzün işleyebileceği büyüklükteki toprağa da "çiftlik" denilmektedir (İnalcık, 1996: 6).

Tablo-10: Irlamaz Köyü Temettuat Defterine Göre Yük ve Binek Hayvanları

\begin{tabular}{|l|c|l|l|l|}
\hline $\begin{array}{l}\text { Hayvan } \\
\text { Cinsi }\end{array}$ & $\begin{array}{l}\text { Hayvan } \\
\text { Sayısı }\end{array}$ & $\begin{array}{l}\text { Sahip Olan } \\
\text { Hane Sayısı }\end{array}$ & $\begin{array}{l}\text { Hane aşına } \\
\text { Ortalama }\end{array}$ & $\begin{array}{l}\text { Toplam Yük ve Binek } \\
\text { Hayvanlarına Oranı (\%) }\end{array}$ \\
\hline Öküz & 63 & 21 & 3 & 45,7 \\
\hline Katır & 1 & 1 & 1 & 0,8 \\
\hline Beygir & 28 & 24 & 1,2 & 20,3 \\
\hline Kısrak & 4 & 4 & 1 & 2,8 \\
\hline Tay & 4 & 4 & 1 & 2,8 \\
\hline Merkeb & 38 & 35 & 1,1 & 27,6 \\
\hline TOPLAM & $\mathbf{1 3 8}$ & & & $\mathbf{1 0 0}$ \\
\hline
\end{tabular}

Yukarıdaki tabloda da görüldüğü gibi, koşum hayvanı olarak öküzün çokluğu dikkat çekmektedir. 1844 yılında Irlamaz Köyü'ndeki kayıtlı öküz sayısı 63'tür. En az bir öküze sahip hane sayısı ise 21'dir. Bu duruma göre, hane başına düşen ortalama öküz sayısı 3'tür. Bu değerlendirme en az bir öküzü olan hanelere göre yapılmıştır. Irlamaz Köyü'nün tamamı değerlendirmeye tabi tutulduğu zaman, hane başına düşen öküz sayısının birin altında olduğu görülmektedir. Genel anlamda bakıldığında, ekonomisi tarıma dayalı 
olduğu düşünülen Irlamaz Köyü için, bu sayının yeterli bir değer taşımadığını düşünmek mümkündür.

Hane bazında değerlendirildiği zaman, hanelerin 1 ile 5 arasında değişen öküze sahip olduğu görülmektedir. 5 öküzü olan hane reisi sayısı 4'tür. Bunlardan birisi Hacı Ahmet Oğlu Mehmet'tir. ${ }^{10} \mathrm{Bu}$ hane reisinin mesleği erbab-1 ziraat olarak kaydedilmiş ve 123 dönüm tarlaya maliktir. Bundan başka yine meslekleri erbab-1 ziraat olan ve 31 dönüm tarlaya sahip Hamza Oğlu Mehmed, ${ }^{11} 16$ dönüm tarlası olan Murad Oğlu İbrahim ${ }^{12}$ ve 37 dönüm tarlası bulunan Benyar Oğlu Halil'dir. ${ }^{13} \mathrm{Hac}$ Ahmet Oğlu Mehmet'ten başka diğer hane reislerinin tarlası çok büyük değildir. Toplam 153 dönüm tarlası olan ve mesleği erbab-ı ziraat şeklinde kayıtlı Menemenli Oğlu Mustafa'nın ise hiç öküzü bulunmamaktadır. ${ }^{14}$

Bu grupta sayısı yüksek olan bir başka hayvan merkebtir. Merkeb yük taşımada kullanıldığı gibi, binek olarak da faydalanılan bir hayvandır. Bunların sayısı ise 38 ve merkebe sahip hane sayısı ise $35^{\prime}$ dir. Bunların toplam yük ve binek hayvanlarına oranı \% 27,6'dır. Merkebi sayı bakımından takip eden diğer bir yük ve binek hayvanı beygirdir. Irlamaz Köyü'ndeki beygirlerin sayısı 28 olup, toplam 24 hanenin en az bir beygiri bulunmaktadır. Beygirlerin toplam yük ve binek hayvanlarına oranı \% 20,3'dür. Kısrak ve tay sayısı birbirine eşit olup, defterde dörder kısrak ve tay kayıtlıdır. Bunlara sahip olan hane sayısı da 4'tür. Yani Irlamaz Köyü’nde hiçbir hanede birden fazla kısrak ve tay yer almamaktadır. Bunların toplam yük ve binek hayvanlarına oranı \% 2,8'dir. Bu grupta miktar bakımından en az olan hayvan ise katır olup, sadece bir hanede 1 katır mevcuttur.

Tablo-11: Irlamaz Köyü'nün Yük ve Binek Hayvanı Sahiplik Oranı

\begin{tabular}{|l|c|c|}
\hline Hayvan Cinsi & Sahip Olan Hane Sayısı & Toplam Hane Sayısına Oranı (\%) \\
\hline Öküz & 21 & 29,2 \\
\hline Katır & 1 & 1,4 \\
\hline Beygir & 24 & 33,3 \\
\hline Kisrak & 4 & 5,5 \\
\hline Tay & 4 & 5,6 \\
\hline Merkeb & 35 & 48,6 \\
\hline
\end{tabular}

\section{c) Arıcilık}

Irlamaz Köyü ekonomisinde pek fazla bir yer tutmamakla beraber, farklı bir uğraş dalı olması sebebiyle arıcılık faaliyeti hakkında da bilgi vermeyi uygun gördük. Köyde sadece 21. hanede kayıtlı Sandal Oğlu Hasan arıcılık yapmaktadır. Defterde bu kişinin mesleği

\footnotetext{
${ }^{10}$ BOA, M.L. VRD. TMT.d. 2762, s.18 hane no:4.

${ }^{11}$ BOA, M.L. VRD. TMT.d. 2762, s.27 hane no:61.

12 BOA, M.L. VRD. TMT.d. 2762, s.20 hane no:12.

${ }^{13}$ BOA, M.L. VRD. TMT.d. 2762, s.24 hane no:46.

${ }^{14}$ BOA, M.L. VRD. TMT.d. 2762, s.18 hane no:3.
} 
erbab-1 ziraat olarak kaydedilmiş olup, 40 kovanı bulunmaktadır. Buradan elde ettiği gelir 320 kuruş, verdiği öşr-i kovan tutarı ise 30 kuruştur. ${ }^{15}$

\section{2- Arazi Dağılımı ve Kullanımı}

\section{a) Arazi Büyüklüğüne Göre İşletmeler}

Osmanlı döneminde bir çiftçinin nadasa bıraktığı ve ekim yaptığı toprakların toplam yüzölçümlerine göre tarım işletmeleri üç sınıfta değerlendirilmektedir. Yüzölçümleri 10 dönümden (Emecen, 1994: 521) ${ }^{16}$ az araziler küçük, 10-50 dönüm arasında olanlar orta, 50 dönüm ve üzerindeki yerler ise büyük işletme şeklinde tasnif edilmiştir (Güran, 1998: 81829). Bu bilgiler ışığında Irlamaz Köyü'nün arazisi değerlendirmeye tâbi tutulduğu zaman, orta büyüklükteki işletmelerin daha çok yer aldığ 1 görülmektedir ${ }^{17}$. Bu şekilde 10 ile 50 dönüm arası arazisi bulunan hane reisi sayısı 36'dır. Toplam 72 hane göz önünde bulundurulduğu zaman, \% 50 oranında hane reisinin orta büyüklükte işletme sahibi olduğu anlaşılmaktadır. Küçük işletme hane reislerinin sayısı 24'tür. Bunun geneldeki payı ise $\% 33,34^{\prime}$ dır. Büyük işletme sahibi hane reislerinin sayısıysa 12 'dir. Toplam haneye nispeti ise \% 16,66'dır. 100 dönümün üzerinde toprağ bulunan sadece 3 hane mevcuttur. Bunlardan en çok araziye sahip olan hane reisi, mesleği erbab-1 ziraat şeklinde geçen Menemenli Oğlu Mustafa'dır. Bu kişinin, 153 dönüm mezru arazisi ve 3 dönüm de bağ1 bulunmaktadır. Bu tarz büyük araziye sahip olan bir diğer hane reisi Hacı Ahmet Oğlu Mehmed ve kardeşi Süleyman'dır. Bunların 123 dönüm mezru, 14 dönüm gayr-i mezru ve 4 dönüm de bağları bulunmaktadır. Ayrıca bağlarının bir miktarını da icara vermişlerdir. 100 dönümün üzerinde toprağa sahip olan başka bir hane reisi ise Davud Oğlu Hüseyin'dir. Bu hane reisinin 81 dönüm mezru, 54 dönüm gayr-i mezru ve 3 dönüm de bağı bulunmaktadır ${ }^{18}$. Bunlara ilişkin istatistikî bilgiler aşağıdaki tabloda gösterilmiştir.

\section{Tablo-12: İşletme Büyüklüklerine Göre Arazi Dağılımı}

\begin{tabular}{|c|c|c|}
\hline Sinıflandırma Türü & Sahip Olan Hane Sayısı & Oranı (\%) \\
\hline Büyük & 12 & 16,66 \\
\hline Orta & 36 & 50 \\
\hline Küçük & 24 & 33,34 \\
\hline Toplam & $\mathbf{7 2}$ & $\mathbf{1 0 0}$ \\
\hline
\end{tabular}

\footnotetext{
${ }^{15}$ BOA, M.L. VRD. TMT.d. 2762, s.21 hane no:21.

${ }^{16}$ Dönüm, Osmanlılarda kullanılan temel arazi ölçü birimidir. Genellikle geniş adımlarla yürüyen birinin adımı ile 40x40 adım karelik bir yüzölçümü birimini ifade eder. Buna “örfi dönüm” adı verilir. Ancak adım aralığı kişiden kişiye değiştiği için, her adım bir mimar arşını (yaklaşık 75, 78 cm.) esas alan bir ölçü birimi ile sabitlenmiş ve buna "şer'î dönüm" adı verilmiştir. Buna göre dönüm yaklaşık olarak 916,8 m² veya 919,302 $\mathrm{m}^{2}$ 'lik bir araziyi göstermektedir. Bkz. Aynı yer.

17 Toprakların değerlendirmeye tabi tutulurken, hanelerin mezru, gayr-i mezru ve bağ arazilerin toplamı göz önünde bulundurulmuştur.

${ }^{18}$ BOA, M.L. VRD. TMT.d. 2762, s.22 hane no:32.
} 


\section{b) Arazi Kullanımı}

Irlamaz Köyü'nün temettuat verilerine göre arazisi 2123 dönümdür. Bu araziler mezru arazi, gayr-i mezru yani nadasa bırakılan arazi, bağ ve yonca bahçesi olarak kullanılmaktadır. Köyde öşr-ü bostan veren sadece bir hane reisi vardır. Fakat kayıtlarda bostan olarak değerlendirilen araziye dair bilgi bulunmamaktadır. Muhtemelen bu hane reisinin kayda geçmeyecek kadar küçük bir bahçesi olduğu ve burada sebze, kavun, karpuz gibi bostan ürünleri yetiştirdiğini söylemek mümkündür.

Tablo-13: Arazilerin Cinsi ve Oranları

\begin{tabular}{|l|c|c|c|}
\hline Arazinin Cinsi & Sahip Hane Sayısı & $\begin{array}{c}\text { Miktarı } \\
\text { (dönüm) }\end{array}$ & Toplam Araziye Oranı (\%) \\
\hline Mezru Tarla & 65 & 1302 & 61 \\
\hline Gayr-i Mezru Tarla & 37 & 624 & 29 \\
\hline Bağ & 43 & 172 & 8 \\
\hline Yonca Bahçesi & 12 & 25 & 2 \\
\hline Toplam & - & $\mathbf{2 1 2 3}$ & $\mathbf{1 0 0}$ \\
\hline
\end{tabular}

Yukarıdaki tabloda da görüldüğü üzere, 2123 dönümlük arazinin 1302 dönümlük miktarı mezru arazi olarak kullanılmaktadır. Toplam topraklara oranı \% 61'dir. Yani toprakların yarısından fazlası mezru araziden meydana gelmektedir. Mezru tarlaya sahip hane sayısı ise, 65'tir. Köyde 71 hane olduğu düşünüldügünde, sadece 6 hanenin ekili dikili tarlası olmadığı görülür. Geri kalan bütün hanelerin ise mezru arazisi bulunmaktadir.

Gayr-i mezru araziye sahip hane reisi sayısı ise 37'dir. Bunların miktarı 624 dönüm olup, toplam araziye oranı \% 29'dur. Bağ arazisine sahip hane reisi sayısı ise $43^{\prime}$ tür. Ancak bağlar dönüm olarak değerlendirmeye tabi tutulduğu zaman çok fazla yer tutmadığ1 görülmektedir. Bağların yekûnu 172 dönüm olup, toplam araziye nispeti \% 8'dir. Hayvan yiyeceği olarak kullanılan yonca için de ayrıca arazi tahsis edilmiş ve temettuat defterinde bu araziler kaydedilmiştir. Yonca bahçesine sahip olan hane reisi sayısı 12' dir. Miktarı ise 25 dönüm olup, toplam araziye oranı ise \% 2' dir.

Tablo-14: Arazi Cinsi Olarak Hane Başına Düsşen Miktar (Dönüm)

\begin{tabular}{|l|c|c|c|}
\hline \multicolumn{1}{|c|}{ Arazinin Cinsi } & Sahip Hane Sayısı & Miktarı & Hane Başına Düşen Miktar $^{\mathbf{1 9}}$ \\
\hline Mezru Tarla & 65 & 1302 & 20 \\
\hline Gayr-i Mezru Tarla & 37 & 624 & 17 \\
\hline Bağ & 43 & 172 & 4 \\
\hline Yonca Bahçesi & 12 & 25 & 2 \\
\hline Toplam & - & $\mathbf{2 1 2 3}$ & \\
\hline
\end{tabular}

${ }^{19}$ Hane başına düşen miktar değerlendirilirken, sadece o arazi cinsine sahip olan hane sayıları temel alınmıştır. 
Yukarıdaki tabloda da arazi türü olarak hane başına düşen miktarlar dönüm cinsinden verilmiştir. Burada da görüldügü gibi, mezru araziye sahip hane reisi sayısı 65'tir. 1844 yılına ait köyün temettuat defterinde 1302 dönüm mezru arazi yer tuttuğuna nispetle, hane başına düşen ortalama değerin 20 dönüm olduğu görülmektedir. Yani her bir hanenin yaklaşık 20 dönüm civarında mezru arazisi bulunmaktadır. Gayr-i mezru arazinin hane başına düşen ortalama miktarı 17 dönümdür. Bağ olarak kullanılan arazinin hane başına düşen payı ise 4 dönümdür. Hane başı dağılımda miktarın en az olduğu arazi yonca bahçesidir. Yonca bahçesi olarak kullanılan alan 25 dönümdür. 12 hanenin sahip olduğu bu arazinin, hane başına denk gelen miktarıysa 2 dönümdür.

Tablo-15: Zeytinlik Olarak Kaydedilen Arazilerin Miktarı ve Hane Başına Ortalaması

\begin{tabular}{|c|c|c|c|}
\hline & & & \\
Arazi Cinsi & Sahip Olan Hane Sayısı & Miktarı (Kıta) & Hane Başına Ortalama \\
\hline Zeytinlik & 25 & 188 & 7,5 \\
\hline
\end{tabular}

Zeytinlik olarak kullanılan arazi türünün miktarı verilmeden, sadece "kıta" ibaresiyle kaydedilmiştir. Dolayısıyla zeytinlik olarak değerlendirilen araziyi ayrı şekilde ele almak durumunda kaldık. Buna göre, toplam 188 kıta zeytinlik arazi bulunmaktadır. En az bir kıta bile olsa zeytinliğe sahip olan hane sayısı $25^{\prime}$ dir.

Tablo-16: Kiraya Verilen Araziler ve Getirisi

\begin{tabular}{|c|c|c|}
\hline Cinsi & Miktar/Dönüm & Getirisi/Krş. \\
\hline Bağ & 5 & 300 \\
\hline Tarla & 10 & 45 \\
\hline
\end{tabular}

1844 Yilında Irlamaz Köyü'nde yine temettuat defterine göre çok olmamakla beraber, arazilerin kiraya verildiği de görülmektedir. Bu bağlamda 5 dönüm bağ ve 10 dönüm tarla kiraya verilmiştir. 5 dönümlük bağın kira geliri 300 kuruş, 10 dönüm tarlanın geliri ise 45 kuruş olarak kaydedilmiştir. Arazilerini kiraya veren hane sayısı ise ikidir. Bunlardan birisi, Abdülkadir Ağa zevcesi Raziye Hanım olup, 10 dönüm tarlasını kiraya vermiş ve buradan 45 kuruş gelir elde etmiştir. Raziye Hanım'ın bu araziden başka toprağı kayıtlı değildir. Tarlasını kiraya veren hane reisi ise, Hacı Ahmet Oğlu Mehmed ve kardeşi Süleyman'dır. Bunların söz konusu araziden başka 153 dönüm tarlaları ve 3 dönüm de bağları bulunmaktadır. Kiraya verilen yerlerin miktar ve değerleri nispetine göre, bağın bir dönümlük kira bedeli 60 kuruş, tarlanın ise 4,5 kuruştur. 


\section{3- Tarım}

Milletler üzerinde yaşadıkları coğrafyayı en iyi şekilde tanıyıp, toprağı ve tabii sathı doğru şekilde kullanabildikleri ölçüde gelişme gösterip, iktisaden de kalkınma sağlayabilmişlerdir. Bu ölçüde siyasi varlıklarını da yüceltip, güçlendirmişlerdir (Kodaman, 1999: 105-106). Osmanlı Devleti, sanayi öncesi tüm devletler de olduğu gibi ekonomisi tarıma dayalı bir sisteme sahipti. Bu yapının güçlü temeller üzerine inşası, organizasyonu ve devamının sağlanması için, o devirde geçerli olan, ziraî hayatın şartları içerisinde, reaya ile toprak arasındaki ilişkilerin düzenli bir şekilde idaresi, aynı zamanda malî ve askerî teşkilatlanmayı da iç içe kılmaktaydı. Bu yolla ortaya çıkan iktisadî kazanç, devlet kurumlarının ve idarenin ana kaynaklarını da oluşturmaktaydı (Özdeğer, 2003: 2).

1844 yılında nüfusça büyük sayılabilecek Irlamaz Köyü'nün ekonomisinin tarıma dayanması ve köyde yaşayanların hayatlarını temin noktasında tarımsal faaliyetlerin en başta yer alması kaçınılmaz bir durumdur. Temettuat defterleri temel olarak, istatistikî bilgi veren defterler olmadığı için, ziraî faaliyetler hakkında direkt bilgilere yer verilmemiştir. Ancak defterlerdeki bir takım ipuçlarından yararlanarak, 1844-1845 yıllarında Irlamaz Köyü'nün ziraî yapısı hakkında bilgi verilmeye çalışılacaktır.

Defterlerde hane başına ne kadar tarım ürünü yetiştirildiği bilgisi yer almamaktadır. Fakat hangi hanenin, hangi üründen ne kadar öşür verdiği, aynî ve nakdî olarak açıcça belirtilmiştir. Hal böyle olunca, üretim miktarı da kendiliğinden ortaya çıkmaktadır. Bilindiği gibi "öşür" kelime olarak onda bir demektir. Öşür veya aşar adı altında her türlü toprak mahsulünden devlet adına alınan vergilerdir (Barkan, 1993: 485). Her hane reisinin toplamda hangi üründen öşür verdiği bellidir. Buradan yola çıkarak da öşrü verilen mahsulün on ile çarpılmasıyla üretilen ürünün miktarını belirlemek mümkündür. Irlamaz Köyü'nde yetiştirilen ürünler 9 çeşit olup, bunlar buğday (hınta), arpa (şa'ir), darı, üzüm, yonca, susam, koza ve zeytindir. ${ }^{20}$ Zeytinin kendisinin değil de yağının öşrü hesaplanmıştır. Buna bağlı olarak, Irlamaz Köyü'nde zeytinciliğin yapıldığı bilinmekle beraber ne kadar zeytin yetiştirildiği hakkında bilgi elde etmek mümkün değildir.

Tablo-17: Yetiștirilen Ürün Miktarı ve Hane Başına Ortalama Miktar

\begin{tabular}{|l|l|l|l|c|}
\hline Cins & Hane Sayısı & Ölçek & Miktar $^{21}$ & $\begin{array}{c}\text { Hane Başına } \\
\text { Ortalama Miktar }\end{array}$ \\
\hline Buğday & 31 & Kile & 2870 & 92,5 \\
\hline Arpa & 20 & Kile & 1140 & 57 \\
\hline Darı & 26 & Kile & 875 & 33,6 \\
\hline Koza(pamuk) & 59 & Kiyye & 23280 & 394,5 \\
\hline Üzüm & 35 & Kiyye & 11070 & 316,2 \\
\hline Zeytin Yağ1 & 20 & Kiyye & 360 & 18 \\
\hline Yonca & 11 & Kuruş & - & - \\
\hline
\end{tabular}

${ }^{20} \mathrm{Koza}$, pamuğun bitki üzerindeki işlenmemiş ham halidir.

${ }^{21} \mathrm{Bu}$ sütundaki değerler, Temettuat defterlerindeki verilen öşürlerin 10 ile çarpılması ile elde edilmiştir. 
Köyde üretilen tarım ürünlerinin en başında koza gelmektedir. Sanayi bitkisi olarak değerlendirebileceğimiz koza, toplam 59 hane tarafından üretilmektedir. 71 hanenin yaşadığı Irlamaz Köyü için bu oldukça yüksek bir rakamdır. Köyün \% 83’nün koza tarımı ile meşgul olduğu görülmektedir. Üretilen koza miktarı ise 23.280 kıyye (Akgündüz, 1992:) olup, 29.844,96 günümüzde kilograma tekabül etmektedir. Yani 1844 yılında Irlamaz Köyü'nde üretilen pamuk kozası 30 tona yakındır. Kozdan bu denli fazla mahsul elde edilmesi, ticarî bir emtia olarak değerlendirildiğini göstermektedir.

Buğday, temettuat kayıtlarında "hınta" olarak geçmektedir. Buğday yetiştiren hane sayısı 31'dir. Irlamaz Köyü’nün yarısına yakınının buğday yetiştirdiği görülmektedir. Verilen öşre göre, köyde yetiştirilen buğday 2870 kile olarak hesaplanmıştır. Bunun günümüzdeki karşılığı yaklaşık olarak 73.632,72 kg'dır. ${ }^{22}$ Temel tüketim gıdası hububat olan toplumlarda, ihtiyacı karşılamak için kişi başına tekabül eden yıllık buğday miktarı 190 ila 235 kg arasında değişmektedir (Bilgi, 2008: 46) Irlamaz Köyü'ndeki toplam buğday hâsılatını $(73.632,72 \mathrm{Kg})$, temettuat verilerine göre çıkardığımız nüfus sayısına (299) böldüğ̈ümüz zaman ise, yılda yaklaşık olarak fert başına $259 \mathrm{~kg}$ buğday düştüğü görülmektedir. Bu durum da 1844 yılında Irlamaz Köyü'nde yetiştirilen buğdayın ihtiyacı karşılayacak kadar olduğu görülmektedir. Genel olarak, Pazar ekonomisi için gerekli alt yapının oluşmadığı yerlerde, buğday üretimi daha ziyade halkın kışlık ihtiyacını karşılayabilecek ölçüde yapılmaktadır (Özçelik, 2005: 79) Bu durumun Irlamaz Köyü için de geçerli olduğunu anlamaktayı.

Arpa, temettuat kayıtlarında "şa'ir" olarak geçmektedir. Arpa, daha çok koşum ve binek hayvanlarının yemi olarak kullanılmaktadır. Bu grup hayvanın Irlamaz Köyü'nde oldukça fazla olduğu göz önünde bulundurulduğu zaman, arpanın yetiştirilmesinin önemi daha açık olarak ortaya çıkmaktadır. Arpa, 20 hane tarafından yetiştirilmekte olup, toplam hane sayısına oranı \%28,16'dır. Yine verilen öşürden yola çıkılarak, yetiştirilen arpa 1140 kile olarak hesaplanmıştır. Bunun da günümüzdeki karşılığı yaklaşık olarak $25.365 \mathrm{~kg} \cdot \mathrm{dir}^{23}$

Hayvan yemi olarak kullanılan ve istihsal edilen bir diğer ürün de darıdır. Bakımının kolaylığ 1 ve iklim olarak dünyanın hemen her yerinde yetiştirilebilen türlerinin olması sebebiyle, tercih edilen tarım ürünlerinin başında gelmektedir (Özçelik, 2005: 97). Irlamaz Köyü'nde hane bazında değerlendirildiği zaman, koza, üzüm ve buğdaydan sonra en fazla tercih edilen ürün olduğu görülmektedir. Ancak, yetiştirilme miktarı diğer ürünlere göre biraz daha düşüktür. Toplam 875 kile darı üretilmiştir.

${ }^{22}$ Kayıtlarda herhangi bir kesin ibare olmamakla birlikte çevre illerin kullandığı ölçü birimi olan İstanbul Kilesi'nin esas alındığı varsayımından hareketle bu sonuca ulaştık. Bir İstanbul Kilesi buğday için 25,656 kg'dır. Bkz. Walter Hınz, İslam'da Ölçü Sistemleri, Çev. Acar Sevim, Marmara Üniversitesi Yayınları, İstanbul 1990, s.51.

${ }^{23} 1$ kile arpa 22.25 kg.dır. Bkz. Hinz, A.g.e., s.51. 
1844 yılında Irlamaz Köyü'nde bağcılığın oldukça gelişmiş olduğunu söylemek mümkündür. Bağcılığın Turgutlu ve çevresi için daha eski tarihlere dayandığı bilinmektedir. Evliya Çelebi seyahatnamesinde Turgutlu hakkında bilgi verirken, şehrin düz bir yerde kurulduğunu bağ ve bahçesinin çok olduğunu ifade etmektedir (Şeker, 1995: 84). Ayrıca Turgutlu'nun üzüm kurusunun, kavunun ve karpuzunun meşhur olduğunu anlatmaktadır (Şeker, 1995: 66). Irlamaz Köyü'nün, Turgutlu'ya yakınlığ1 düşünülürse, aynı şeyleri burası için de söylemek mümkündür. Çünkü temettuat kayıtları hane bazında değerlendirildiği zaman, kozadan sonra en fazla üretimi yapılan tarım ürünün üzüm olduğu görülmektedir. Bununla birlikte bağ sahibi 43 hane reisinin bulunması ve arazilerin 172 dönümünün bağ olarak kullanılması, Irlamaz Köyü'ndeki bağcılığa verilen önemi ortaya koymaktadır. Verilen öşürlerden yola çıkılarak, köyde yetiştirilen üzüm miktarı 11.070 kıyye olarak hesaplanmıştır. Temettuat kayıtlarında üzümün nasıl değerlendirildiğine dair ipucu bulmak mümkün değildir. Halkın, bu üzümlerin bir kısmını taze olarak tükettiği, bir kısmını kurutarak kışlık ihtiyacı için sakladığı ve pekmez yapımında kullandığını düşünmek mümkündür. Üretilen miktarın fazlalığı göz önünde bulundurulursa, üzümün kurusunun ve pekmezinin fazlasının satıldığı muhakkaktır. Lâkin kayıtlarda bu hususa ait bir bilgi bulunmamaktadır.

1844 yılında köyde zeytinciliğin yapıldığına anlamak mümkündür. Çünkü yukarıda da belirtildiği gibi kayıtlarda "zeytinlik" olarak geçen arazi türü bulunmaktadır. Bu arazilerin miktarı verilmeden sadece "kıta" olarak kaydedilmiştir. Buna göre, toplam 188 kıta zeytinlik olarak kullanılan arazi bulunmakta olup, en az bir kıta bile olsa zeytinliğe sahip olan hane sayısı 25'dir. Bu 25 haneden 20 tanesinin zeytinden yağ elde ettiği anlaşılmaktadır. Çünkü 20 hane reisi zeytinyağı öşrü vermiştir. Verilen bu öşürlerden yola çıkılarak, üretilen zeytinyağı miktarı 360 kıyye olarak hesaplanmıştır. Bu miktarın çok fazla olmadığı göz önünde bulundurulduğu zaman, halkın zeytinyağını ticaretini yapmak için değil, kendi ihtiyaçları için ürettiğini söylememek mümkündür.

Yonca toplam 11 hane tarafından yetiştirilmektedir. Fakat yonca yetiştirilme miktarı defterde belirtilmemiş, sadece kuruş cinsinden değeri verilmiştir. 178 kuruşluk yonca öşrü tahsil edilmiş olup, buradan üretilen yoncanın değerinin toplamda 1780 kuruş olduğunu hesaplamak mümkündür.

Tablo-18: Yetiştirilen Susam Miktarı ve Hane Başına Düşen Ortalama Miktar

\begin{tabular}{|l|l|l|l|}
\hline \multicolumn{1}{|c|}{ Susam } & Miktar & Değer/Krş. & Hane Sayıs1 \\
\hline Ayar & 110 & 1000 & 9 \\
\hline Çeki & 150 & 3000 & 9 \\
\hline Şinik & 210 & 1040 & 20 \\
\hline Toplam & - & 5040 & 38 \\
\hline
\end{tabular}

İncelemiş olduğumuz defterde susam miktarları tek bir cins olarak verilmemiştir. Bazı haneler için ayar, bazı haneler için çeki, bazı haneler için de şinik olarak kaydedilmiştir. Biz de bu kayıtlara sadık kalarak susam miktarını o şekilde vermeyi uygun bulduk. Buna göre, 1844 yılında 110 ayar, 150 çeki ve 210 şinik susam üretilmiştir. Bu miktarın tekabül 
ettiği toplam değer ise 5040 kuruştur. Bilindiği gibi susam, sanayi bitkileri arasında yer almaktadır. Susam yağı için kullanıldığı gibi, üzüm suyu ile susamın yağlı posasından tahin helvası elde edilmektedir.

\section{C- Irlamaz Köyü'nün 1844 Yılı Gelirleri}

Irlamaz Köyü'nde gelir türleri ele alındığında, tarım, hayvancılık, meslek ve icar geliri olmak üzere 4 grupta incelemek mümkündür. Tarım grubu ekili dikili tarlalardan elde edilen gelirden müteşekkildir. Bu gelirler temettuat defterlerinde açıç̧a belirtilmiştir. Temettuat kayıtlarında önce tarlanın dönüm cinsinden miktarı belirtilmiş sonra da tarladan elde edilen hasılat yazılmıştır. Kayıtlarda tarlaya ne ekildiği hususunda açık bir bilgi bulunmamaktadır. Sadece tarladan elde edilen toplam hâsılat verilmiştir. Fakat hâsılatın neye göre hesaplandığı açıkça ifade edilmemiştir. 123 dönüm mezru tarlaya sahip olan, Hacı Ahmet Oğlu Mehmed'in tarla geliri 2886 kuruş olarak geçerken, 30 dönüm mezru tarlası olan Hamza Oğlu Mehmed'in tarla geliri 6239 kuruş olarak kaydedilmiştir. 123 dönümlük tarlanın bir dönümünden gelir 23,46 kuruşa tekabül ederken, 30 dönümlük tarlanın bir dönümünden 207,96 kuruş gelir elde edilmiştir. Buradan yola çıkarak, tarla gelirlerinde kişilerin beyanının esas alındığı ortaya çıkmaktadır.

Tablo-19: Gelirlerin Dağılımı ve Yüzdelik Oranları

\begin{tabular}{|l|l|l|}
\hline Gelirin Cinsi & Miktarı (krş) & Oranı (\%) \\
\hline Tarım & 180.041 & 96,12 \\
\hline Hayvancilık & 3.820 & 2,04 \\
\hline İcar & 345 & 0,18 \\
\hline Meslek & 3.100 & 1,66 \\
\hline Toplam & $\mathbf{1 8 7 . 3 0 6}$ & \\
\hline
\end{tabular}

Irlamaz Köyü'nün tarımdan elde edilen geliri 180.041 kuruş olarak kaydedilmiştir. Bunun toplam gelir içerisindeki oranı zaman, \% 96,12' dir. Bu durum da bize, Irlamaz Köyü'nün gelirinin büyük bir çoğunluğunu tarımdan elde ettiğini göstermektedir. Tarım geliri olan toplam hane sayısı 65'tir. 6 hane reisi için herhangi bir tarım geliri kaydedilmemiştir. Toplam tarım gelir olan 180.041 kuruş, tarımla uğraşan hane sayısına bölündüğü zaman, hane başına düşen gelir 2769,86 kuruş olarak hesaplanmıştır.

Tarım gelirleri arasına, mezru tarla, bağ, yonca bahçesi ve zeytin ağaçlarından elde edilen gelirler dâhil edilmiştir. Mezru tarlaların miktarı 1302 dönüm ve toplam gelir 166.883 kuruştur. Bunun hane başına ortalaması ise 2.567,43 kuruştur. Bağcılık yapan hane sayısı 43 olup, toplam 172 dönüm bağ bulunmaktadır. Bağcılıktan elde edilen gelir ise 5.984 kuruştur. Bağcılıkla uğraşan haneler değerlendirmeye alındığı zaman, hane başına 
düşen bağ geliri ortalaması 139,16 kuruştur. Yonca bahçesi gelirleri ise, 4.198 kuruş olup, hane başına düşen ortalaması 349,33 kuruştur.

Tarım gelirlerinden bir diğeri zeytinciliktir. Zeytinlik olarak ayrılan arazinin miktarı verilmediği için, ne kadar zeytinlik alan olduğunu tespit etmek mümkün olmamıştır. Zeytin ağacı sahibi hane reisi sayısı 25'tir. Toplam 188 parçadan meydana gelen zeytinlikten elde edilen gelir 2.976 kuruştur. Bu gelirin hane başına düşen ortalaması ise, 119,04 kuruş olarak hesaplanmıştır.

Tablo-20: Tarım Gelirlerinin Dağılımı ve Hane Başına Ortalaması

\begin{tabular}{|l|c|l|c|c|}
\hline \multicolumn{1}{|c|}{ Cinsi } & $\begin{array}{l}\text { Sahip Hane } \\
\text { Sayısı }\end{array}$ & Miktar/Dönüm & $\begin{array}{c}\text { Getirisi/ } \\
\text { Krş. }\end{array}$ & $\begin{array}{c}\text { Hane Başına } \\
\text { Ortalama (Krş) }\end{array}$ \\
\hline Mezru Tarla & 65 & 1302 & 166.883 & $2.567,43$ \\
\hline Bağ & 43 & 172 & 5.984 & 139,16 \\
\hline Yonca Bahçesi & 12 & 25 & 4.198 & 349,33 \\
\hline Zeytin Ağacı & 25 & 188 (parça) & 2.976 & 119,04 \\
\hline TOPLAM & - & - & 180.041 & - \\
\hline
\end{tabular}

19. yüzyıl ortalarında tipik bir Anadolu köyünün bütün özelliklerini yansıtan Irlamaz'da, tarım gelirlerini hayvancılık geliri takip etmektedir. Ancak hayvancılık geliri, genel gelir içerisinde çok fazla bir yer tutmamaktadır. Hayvancılık gelirleri hesaplanırken, sağman inek, sağman manda ve arıcılıktan edilen gelir dâhil edilmiştir. Kayıtlarda sağman manda için 100 kuruş, sağman inek için de 50 kuruş gelir kaydedilmiştir. Bu gelirin hayvandan nasıl elde edildiği açıkça ifade edilmemesine rağmen, sağman inek ve mandadan elde edildiği için, süt geliri olabileceği izlenimi vermektedir. Fakat süt verimi ve hâsılatı ile ilgili bilgiler temettuat defterlerinde yer almamaktadır.

Irlamaz Köyü'nde 1844 yılında 24 sağman manda ve 22 sağman inek kaydedilmiştir. Bundan başka, 1 hane reisinin 40 arı kovanından 320 kuruş geliri bulunmaktadır. Bunlardan elde edilen toplam gelir 6.920 kuruş olarak görülmektedir. Bu gelir, toplam gelirin \% 3,63'ünü oluşturmaktadır. En az bir inek veya mandası olan hane sayısı 41'dir. ${ }^{24}$ Hayvancılıktan elde edilen gelirin hane başına düşen ortalama miktarı 164,76 kuruş ve bunun toplam gelirdeki oranı ise \% 2,04'tür.

Defterde bir diğer gelir türü olarak meslek gelirlerini görmekteyiz. Bunlar imamlık, kahvecilik, amelecilik ve ne mesleği olduğu belirtilmeden "mesleğinden" olarak kaydedilen gelirlerdir. 1 hane reisinin imamlıktan geliri 200 kuruş, 1 hane reisinin kahvecilik geliri 250 kuruş, 10 hane reisinin amelecilikten geliri 2.350 kuruş ve diğer bir hane reisinin mesleğinden geliri 300 kuruş olarak kaydedilmiştir. Meslek gelirlerinin toplamı 3.100 kuruştur. Söz konusu gelirlerinin toplam gelire oranı ise \% 1,66' dır.

\section{Tablo-21: Meslek Gelirlerin Mesleklere Göre Dağılımı}

${ }^{24}$ Verilere gelir getirmeyen düve ve dana yetiştiren haneler dâhil edilmemiştir. Sadece en az bir sağman ineği veya mandası olan haneler dâhil edilmiştir. 
TEMETTUAT KAYITLARINA GÖRE ERMENAS (IRLAMAZ) KÖYÜ’NÜN SOSYOEKONOMIK DURUMU (1844-1845)

\begin{tabular}{|l|c|c|}
\hline Mesleğin Adı & Hane Sayısı & Gelir(Krş) \\
\hline İmamlık & 1 & 200 \\
\hline Kahvecilik & 1 & 250 \\
\hline Amelecilik & 10 & 2350 \\
\hline Diğer & 1 & 300 \\
\hline Toplam & $\mathbf{1 3}$ & $\mathbf{3 1 0 0}$ \\
\hline
\end{tabular}

\section{D- Irlamaz Köyü'nde Alınan Vergiler}

1844 yılında Irlamaz Köyü'nde verilen vergiler ikiye ayrılmaktadır. Bunlardan birisi "sene-i sabıkada verilen vergi", diğeri ise öşürdür. Öşrün kelime anlamı onda bir demektir. Terim olarak anlamı ise, Osmanlı Devleti'nde halkın ziraî faaliyetler sonucunda ürettiği toprak mahsullerinden alınan vergiye verilen isimdir (Pakalın, 2004/II: 746). İncelemiş olduğumuz defterlerde hane reisleri için "sene-i sabıkada vergisi" yazıldıktan sonra, kuruş cinsinden miktar belirtilmektedir. Vergiy-i mahsusa, 1840 yılından itibaren tatbik edilmeye başlanan bir vergidir. Bazı istisnalar dışında ekonomik durumuna göre herkesten alınmaya çalışılmıştır. Bu verginin miktarı liva ölçeğinde belirlenirdi. Bu miktar livaya bağlı kazalar arasında bölüştürülürdü. Sonra kazanın müdür ve meclis azaları, nüfusun etnik özelliğine göre imam, papaz ve kocabaşı gibi kişilerin katıldığı toplantıda kasaba ve köylere düşen miktar tespit edilir en sonunda da köy ve mahalle düzeyinde kişilerin ödeme güçlerine göre paylaştırılırdı. Bu yeni vergi uygulamasında malî gücün ölçüsü olarak, halkın emlak, arazi ve hayvanı, ticaretle uğraşıyorsa geliri esas alınmakta idi. Bu vergiyi köy veya mahallenin muhtarı, kocabaşı, imamı veya papazı yapardı. Tahsil ettikleri miktarı hane reisinin adının bulunduğu tevzî defterine kaydederlerdi. Sonra parayla birlikte defteri kazaya götürürler ve herkesin ödediği vergi kaza meclisindeki deftere işlenip tevzî defterine gelen paranın tutarı ve tarihi yazılıp, müdür ve sandık emini tarafından mühürlenirdi. Verginin tahsilâtında ve muhassıllara tesliminde güvenliği sağlamak için zabtiye askerleri de görevlendirilirdi(Öztürk, 1996:174-175).

Irlamaz Köyü Temettuat Defterleri'nde öşürler "aşar ve rüsumatı" ifadesinden sonra yazılmış, ürünün altına da ondan alınan aynî ve nakdî miktar ayrı ayrı belirtilmiştir. Bu durum köyde üretilen ürünlerinin miktarını belirlemeye yararken, aynı zamanda ürünlerin rayiç bedellerini ortaya koyması bakımından önemlidir. Köyde küçükbaş hayvancılık yapılmadığı için, "resm-i ağnam” yer almamaktadır. Sadece bir hanenin “öşr-i bostan" ve bir hanenin de “öşr-i kovan” verdiği görülmektedir. Bostan, bahçe ürünlerinden, kovan ise arıcılık faaliyetinden alınan öşürdür.

Köyde 71 hane reisinden 69'u vergi vermektedir. Vergi vermeyen hane reislerinden birisi Hacı Mahmud Oğlu Mahmud olup, meslek hanesine "fukura zümresinden" 
yazılarak, vergi veremeyecek kadar fakir olduğu belirtilmiştir. Bir diğeri, Sarı Mahmud Oğlu Mehmed'in kardeşi Hüseyin'dir. Hüseyin, ayrı bir hane de kaydedilmiş ve meslek hanesine "asakir-i nizamiye-i şahanede" ifadeleriyle askerde olduğu belirtilmiştir. Bununla birlikte muhtar ve imam gibi kamu görevlileriyle kadınların da vergi verdikleri görülmektedir. Defterdeki vergiler, 10 kuruş ile 500 kuruş arasında değişmektedir. En çok vergiyi, mesleği erbab-1 ziraat olarak kaydedilen, Menemenli Oğlu Mustafa vermiş olup, verdiği vergi 500 kuruştur. En az vergiyi ise, Kara Ahmet Oğlu Mehmed zevcesi Ümmühan vermiş olup, bu kadının verdiği vergi 10 kuruştur. Ümmühan'ın tek gelir kalemi bağ olarak geçmektedir. Bu bağlamda Irlamaz Köyü'nde toplanan vergilerin miktarı 11.983 kuruş olarak görülmektedir. Vergi veren hane reisleri değerlendirmeye tâbi tutulduğu zaman, hane başına düşen ortalama vergi miktarı 173,66 kuruş olarak hesaplanmaktadır.

Tablo-22: Hane Başına Düşen Vergi Ortalaması

\begin{tabular}{|c|c|c|c|}
\hline $\begin{array}{l}\text { Vergi veren } \\
\text { Hane Sayısı }\end{array}$ & $\begin{array}{l}\text { Vermeyen Hane } \\
\text { Sayısı }\end{array}$ & $\begin{array}{l}\text { Verilen Toplam } \\
\text { Vergi }\end{array}$ & $\begin{array}{l}\text { Hane Başına Düşen } \\
\text { Ortalama Vergi }\end{array}$ \\
\hline 69 & 2 & 11.983 & 173,66 \\
\hline
\end{tabular}

Irlamaz Köyü'nde öşür alınan ürünler, buğday, arpa, darı, susam, koza, üzüm, zeytinyağ1 ve yoncadır. Bunlardan başka bir hane öşr-i bostan, bir hane de öşr-i kovan vermiştir. Susam öşrü ayar, çeki, şinik cinsleriyle diğer öşürler ise kile ve kıyye cinsinden hem aynî olarak, hem de kuruş cinsinden nakdî şekilde belirtilmiştir. Sadece yonca öşrü aynî olarak kaydedilmemiş, sadece nakdî değeri belirtilmiştir.

En fazla öşür verilen mahsul kozadır. Koza öşrü veren hane sayısı 59'dur. Koza öşrü, kıyye cinsinden belirtilmiş olup, toplam 2.328 kıyyedir. Hane başına ortalama öşür miktarı ise, 39,45 kıyyedir. Kozadan sonra hane bazında en fazla öşür verilen mahsul üzümdür. 35 hane toplam, 1.107 kıyye üzüm öşrü vermiştir. Üzümün hane başına düşen öşür miktarı ise, 31,62 kıyyedir. Kıyye cinsinden öşür verilen bir diğer ürün zeytinyağıdır. 20 hane tarafından, 36 kıyye zeytinyağı öşrü verilmiştir. Hane başına düşen miktar ise, 1,8 kiyyedir.

Hububat ürünlerinden en fazla hanenin verdiği öşür buğdaydır. Buğday öşrü 31 hane tarafından 287 kile verilmiştir. Bunun hane başına düşen miktarı 9,25 kiledir. Buğdaydan başka 26 hane tarafından 87,5 kile darı, 20 hane tarafından 114 kile arpa öşrü verilmiştir. Darının hane başına düşen miktarı 3,36 kile, arpanın ise 5,7 kiledir. Öşür kaydedilen bir diğer ziraî ürün yoncadır. Fakat yoncanın öşrü aynî olarak belirtilmemiş, sadece nakdî olarak yazılmış olup, 11 hane tarafından 178 kuruş yonca öşrü kaydedilmiştir. Yine susam öşrü de farklı ölçü birimleriyle ifade edilmekle beraber toplam 38 hane tarafından 504 kuruş susam öşrü verilmiştir. Bunu hane başına düşen ortalama değeri 13,2 kuruştur.

Tablo-23: Toplanan Öşürlerin Aynî Olarak Cinslerine Göre Dağılımı

\begin{tabular}{|l|l|l|l|l|}
\hline Cins & Hane Sayı̈ı & Ölçek & Miktar/Aynî & Hane Başına Ortalama Miktar \\
\hline
\end{tabular}




\begin{tabular}{|l|l|l|l|l|} 
Buğday & 31 & Kile & 287 & 9,25 \\
\hline Arpa & 20 & Kile & 114 & 5,7 \\
\hline Dar1 & 26 & Kile & 87.5 & 3,36 \\
\hline Koza & 59 & Kiyye & 2328 & 39,45 \\
\hline Üzüm & 35 & Kiyye & 1107 & 31,62 \\
\hline Zeytin Yağ1 & 20 & Kiyye & 36 & 1,8 \\
\hline Toplam & & & - & \\
\hline
\end{tabular}

Öşürlerin miktarına göre aynî ve nakdî değerleri nispetiyle yapılacak sıralamanın benzer olduğu görülmektedir. Miktar olarak en fazla öşür, 5.018 kuruşla kozadan alınmıştır. İkinci sırada gelen buğday öşrünün miktarı ise, 2.583 kuruştur. Darı öşrünün miktarı 525 kuruş, susamdan alınan 507 kuruş, arpa öşrünün miktarı 456 kuruş, üzüm öşrünün miktarı 295 kuruş, yoncanın öşrü 178 kuruş ve zeytinyağının öşrü ise 136 kuruştur. Bu haliyle ziraî ürünlerden alınan toplam öşür miktarı 9.698 kuruş olarak hesaplanmiştır.

Tablo-24: Öşürlerin Nakdî Olarak Dağılımı

\begin{tabular}{|l|c|c|c|}
\hline \multicolumn{1}{|c|}{ Cins } & Hane Sayısı & Değer/Krş. & Hane Başına Ortalaması(krş) \\
\hline Buğday & 31 & 2583 & 83,32 \\
\hline Arpa & 20 & 456 & 22,8 \\
\hline Dar1 & 26 & 525 & 20,19 \\
\hline Koza & 59 & 5018 & 85,05 \\
\hline Üzüm & 35 & 295 & 8,42 \\
\hline Zeytinyağ1 & 20 & 136 & 6,8 \\
\hline Yonca & 11 & 178 & 16,18 \\
\hline Susam & 38 & 507 & 13,3 \\
\hline Toplam & - & 9698 & - \\
\hline
\end{tabular}

Öşr-i bostanın da dahil edilmesi sonucunda Irlamaz Köyü'nün toplam öşür miktarı 9700 kuruştur. Bunların değerlerinin ayrı ayrı yüzdelik oranları hesaplandığı zaman, \% 52'lik payla kozanın birinci sırada yer aldığı görülmektedir. Bir başka ifade ile Irlamaz Köyü'nün öşürlerinin yarısından fazlası kozadan toplanmıştır. Kozayı \% 27 ile buğday, \% 5,5 ile darı ve susam, \% 5 ile arpa, \% 3 ile üzüm, \% 1 ile yonca ve zeytinyağ 1 takip etmektedir. En az öşür miktarı öşr-i bostan olup, \% 0,02 kuruş olarak kaydedilmiştir. 
Tablo-25: Nakdî Olarak Hesaplanan Öşürlerin Cinslerine Göre Yüzdelik Dağılımı

\begin{tabular}{|l|c|c|}
\hline \multicolumn{1}{|c|}{ Cins } & Değer/Krş. & Oran (\%) (Yaklaşı) \\
\hline Buğday & 2583 & 27 \\
\hline Arpa & 456 & 5 \\
\hline Darı & 525 & 5,5 \\
\hline Koza & 5018 & 52 \\
\hline Üzüm & 295 & 3 \\
\hline Zeytinyağ1 & 136 & 1 \\
\hline Yonca & 178 & 1 \\
\hline Susam & 507 & 5,5 \\
\hline Öşr-i Bostan & 2 & 0,02 \\
\hline Toplam & $\mathbf{9 7 0 0}$ & \\
\hline
\end{tabular}

Bunlardan başka Irlamaz Köyü'nde bu dönemde alınan diğer bir vergi çeşidi de resm-i kovandır. Resm-i kovan, arıcılık faaliyetinden alınan bir öşürdür. 40 kovanı olan tek bir hane tarafından 30 kuruş resm-i kovan verilmiştir.

\section{Sonuç}

Köyle ilgili en eski bilgi 1530 yılına aittir. Bu dönemde adı Ormenos olarak geçen köy, nahiyenin merkez köyü olan Turudlu (Turgutlu) Köyü ile beraber Yengi Nahiyesi'ne bağlıdır. 1531 yılında köyde 66 hane, 1575 yılında ise 70 hane bulunmaktadır. Zamanla Ormenos ismi, Ermenas şekline dönüşmüştür. 1842 yılına ait nüfus defterinde köyde 63 hane, 1844 yılı temettuat kayıtlarında 71 hane mevcuttur. 1891 yılına gelindiğinde ise köydeki hane sayısı 115'i bulmuştur. Köyün Cumhuriyet'ten sonra ismi Irlamaz olarak son halini almıştır.

19. yüzyıl ve öncesine ait dönemde köyde gayrimüslim nüfusun varlığına ilişkin bir bilgiye ulaşılamamıştır. Fakat bugün köyde bulunan metruk bir kiliseden ve Irlamaz ahalisiyle yapılan görüşmeler neticesinden, 1920'li yılların başına kadar, az sayıda da olsa Rum'un köyde yaşadığı anlaşılmıştır. Muhtemelen Rumların Irlamaz'a gelişi, 19. yüzyılın sonlarına doğrudur.

Irlamaz Köyü 1844 yılında Turgutlu Kazasına bağlı bir köydür. 1844/1845 yılında köyde 71 hane ve 72 vergi mükellefi bulunmaktadır. Bunlardan 2 hane reisi vergiden muaftır. Diğer hanelerin hepsine az veya çok vergi tahakkuk ettirilmiştir. Köyün hane sayısından yola çıkılarak, 1844 yılı için nüfus, 284 olarak hesaplanmıştır.

Irlamaz'da şahsi lakap olarak yer isimlerinden kaynaklanan Kızılcalı, Sakızlı ve Barsalı; mesleklerden kaynaklanan çulha, hallaç ve kiremitçi; dış görünüşten kaynaklanan kara, topal ve köse; dinî durumu yansıtan hacı lakapları kaydedilmiştir. Köyde 40 farklı sülale adı görülmekte olup, en fazla görülen sülale isimleri, Hacı Mahmud Oğlu, Hallac Oğlu, Hamza Oğlu ve Kara Ahmet Oğlu'dur. Bunların hepsinin kullanılma sıklığı 3’tür. 
Köyde en fazla görülen meslek türü rençberlik olup, toplam 23 hane reisini içermektedir. Bunu 21 erbab-1 ziraat, 12 ameleci, 2 ırgat, birer çulha, imam ve kahveci meslekleri takip etmektedir. 6 hane reisi için herhangi bir meslek yazılmazken, 1 hane reisinin hastalıklı, 1 hane reisinin fukara zümresinden ve 1 hane reisinin ise askerde olduğu belirtilmiştir.

Irlamaz Köyü'nün temel geçim kaynağı tarım ve hayvancllıktır. Hayvancilığın, büyükbaş hayvancilık, yük ve binek hayvancilı̆̆ ile arcılıktan teşekkül ettiği görülmektedir. Büyükbaş hayvancllık olarak manda ve inek besiciliği yapıldığı anlaşılmaktadır. Yük ve binek hayvanı olarak ise, öküz, beygir, merkep gibi hayvanlar yetiştirilmektedir. Küçükbaş hayvancilığın yapıldığına dair ise bir kayıta rastlanılmamıştır.

Arazilerin büyük bir kısmının mezru tarlaya tahsis edildiği Irlamaz Köyü'nde, gayr-i mezru tarla, bağ, yonca bahçesi ve zeytinlik de bulunmaktadır. Tarım ürünü olarak, buğday, arpa, darı, koza, susam, üzüm, zeytin ve yonca yetiştirilmektedir. Bu ürünlerden en fazla mahsul elde edilen tarım ürünleri koza, üzüm ve buğdaydır.

1844 yılında Irlamaz Köyü'nün başlıca gelirleri, tarım, hayvancılık ile kiraya verilen arazilerden ve mesleklerden elde edilen gelirdir. Bunlardan en fazla gelire sahip grup, hayvancılıktır. İcara verilen araziler ise tarla ve bağdır.

Irlamaz Köyü'nde alınan vergilerin başında vergiy-i mahsusa gelmektedir. Bundan başka toprak ürünlerinden alınan öşür, bahçelerden alınan öşr-i bostan ve arıcılıktan alınan resm-i kovan görülmektedir. 


\section{KAYNAKLAR}

1308 Tarihli Aydın Vilayet Salnamesi.

AKGÜNDÜZ Ahmed, Osmanlı Kanunnameleri ve Hukuk Tahlilleri, C.II, Osmanlı Araştırmaları Vakfı, İstanbul 1992.

BARKAN Ömer Lütfi, "Tarihi Demografi Araştırmaları ve Osmanlı Tarihi”, Türkiyat Mecmuası C. X, İstanbul Üniversitesi Türkiyat Enstitüsü Yayınları 1953.

BİLGİ Nejdet, "Temettuat Defterlerine Göre XIX. Yüzyılın Ortalarında Salihli”, Türk İncelemeleri Dergisi, C.XXIII, S.1, Temmuz 2008.

BOA, M.L. VRD. TMT.d. 2762.

BOA, Nfs.d. 2894.

ÇAĞLAR İlker Mümin, Tanzimat'tan II. Meşrutiyet'e Turgutlu, Basılmamış Doktora Tezi, Manisa 2014.

EMECEN Feridun M., XVI. Asırda Manisa Kazası, TTK Yayınları, 1989 Ankara.

EMECEN Feridun M., “Dönüm”, DİA, C.IX, İstanbul 1994.

GÜRAN Tevfik, "Osmanlı Tarım Ekonomisi”, Türk İktisat Yıllığı, S.1, İstanbul 1987.

GÜRAN Tevfik, 19.Yüzyıl Osmanlı Tarımı, Eren Yayıncllık, İstanbul 1998.

HINZ Walter, İslam'da Ölçü Sistemleri, Çev. Acar Sevim, Marmara Üniversitesi Yayınları, İstanbul 1990.

İNALCIK Halil, Osmanlı İmparatorluğu: Toplum ve Ekonomi, Eren Yayıncılık, İstanbul 1996.

KÜTÜKOĞLU Mübahat S., “Osmanlı Sosyal ve İktisadi Tarihi Kaynaklarından Temettü Defterleri (6 belge ile birlikte)", Belleten, C.LIX, S.225, 1995 Ağustos.

MARDIN Şerif, Türk Modernleşmesi, İletişim Yayınları, İstanbul 1995.

NAKRACAS Georgios, Anadolu ve Rum Göçmenlerinin Kökeni, İstanbul 2005.

ÖZÇELIK Selahittin, XIX. Yüzyılda Honaz Kazasında Sosyal ve Ekonomik Hayat (Temettuat Defterlerine Göre), Fakülte Kitabevi, Isparta 2005.

ÖZTÜRK Said, “Temettuat Tahrirleri”, Akademik Araştırmalar Dergisi, S.4-5, 2000.

ÖZTÜRK Said, Tanzimat Döneminde Bir Anadolu Şehri: Bilecik, Kitabevi Yayınları, İstanbul 1996.

PAKALIN M. Zeki, Osmanlı Deyimleri ve Terimleri Sözlüğü, C.II. Milli Eğitim Bakanlığı Yayınları, İstanbul 2004.

ŞEKER Mehmet, "Evliya Çelebi Seyahatnamesine Göre Turgutlu ve Sosyal Hayatı", Turgutlu Sosyo- Ekonomik Tarihi Sempozyumu (Bildiriler) Turgutlu 4-5 Eylül 1995. ŞEMSEDDİN Sami, Kâmûs-ı Türkî, Çağrı Yayınları, İstanbul 2004. 


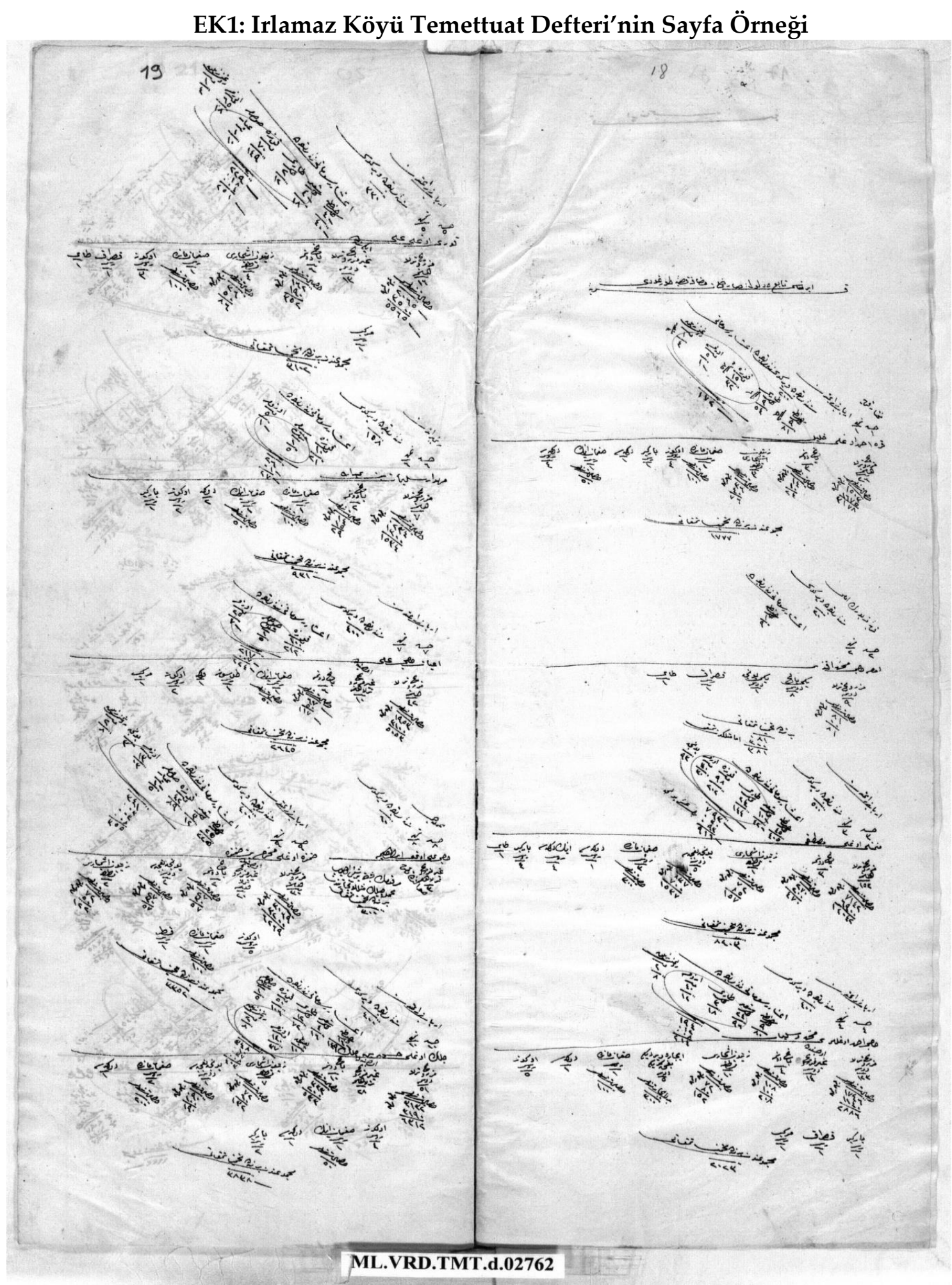


EK2: Irlamaz Köyü'nün Genel Görüntüsü

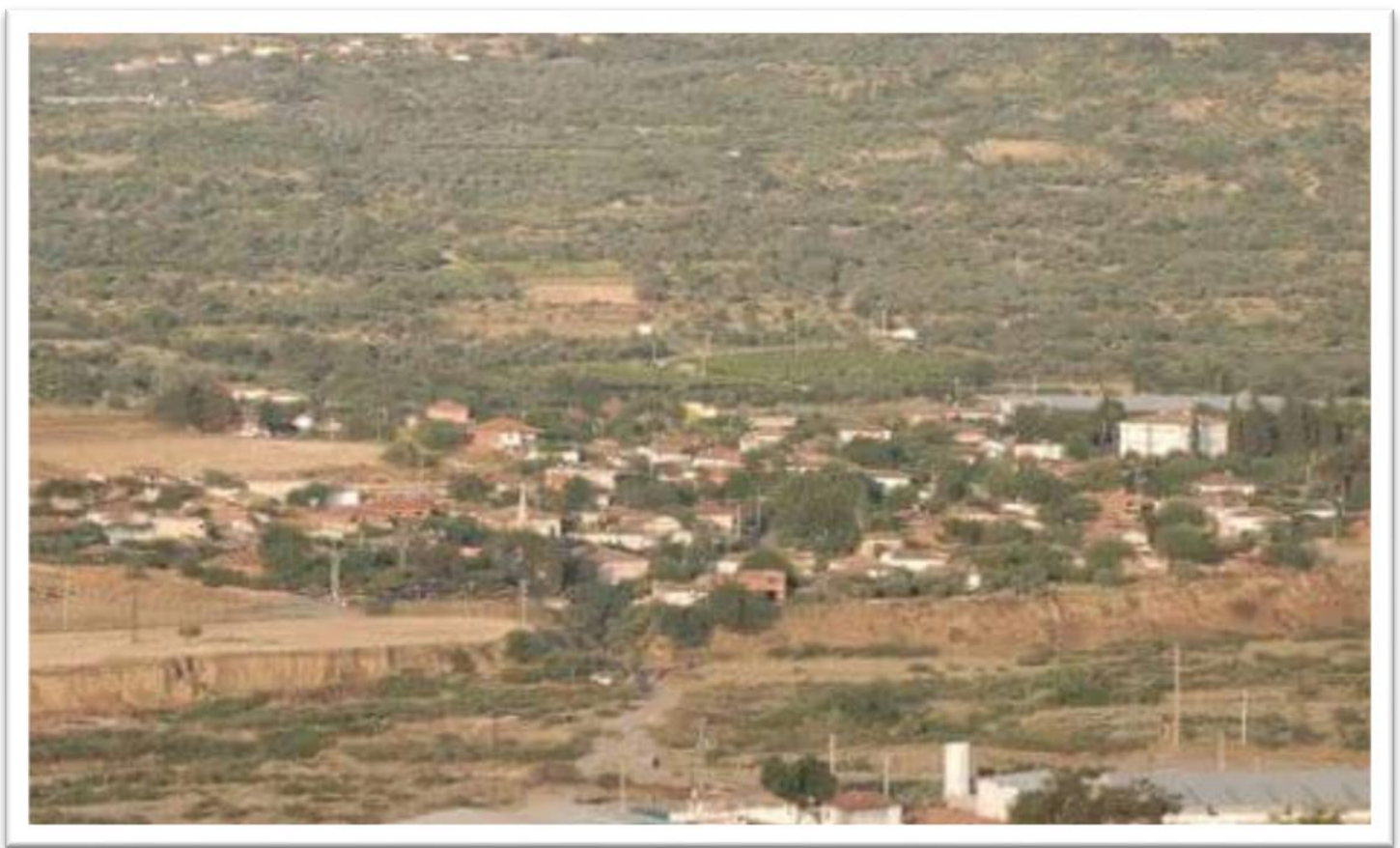

EK1: Irlamaz Köyü'nde Bulunan Kilise

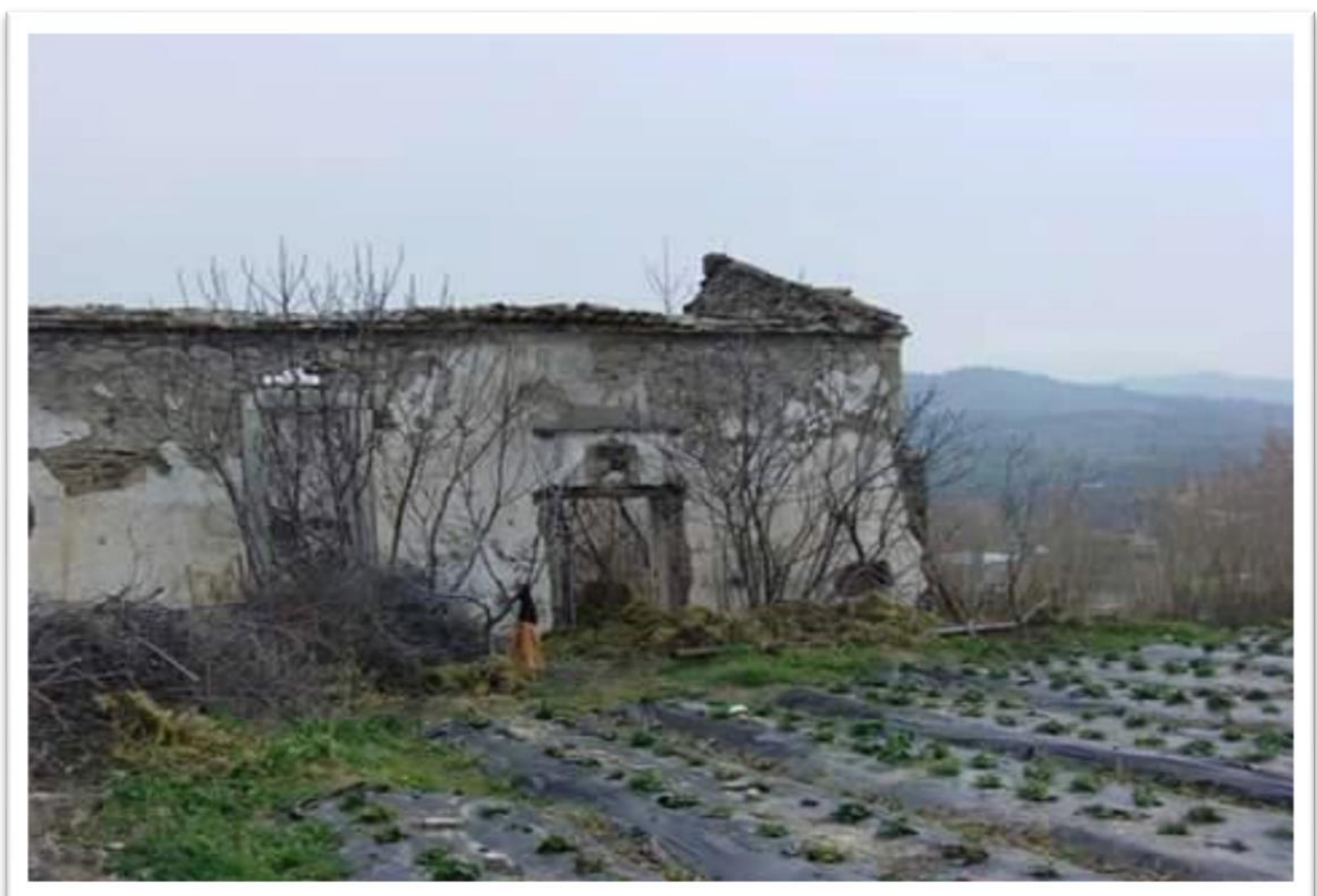


TEMETTUAT KAYITLARINA GÖRE ERMENAS (IRLAMAZ) KÖYÜ’NÜN SOSYOEKONOMIKK DURUMU (1844-1845)

EK2: Irlamaz Köyü'nde Bulunan Kandiren Dede Türbesi ve Mezarlığının Bulunduğu Tepe

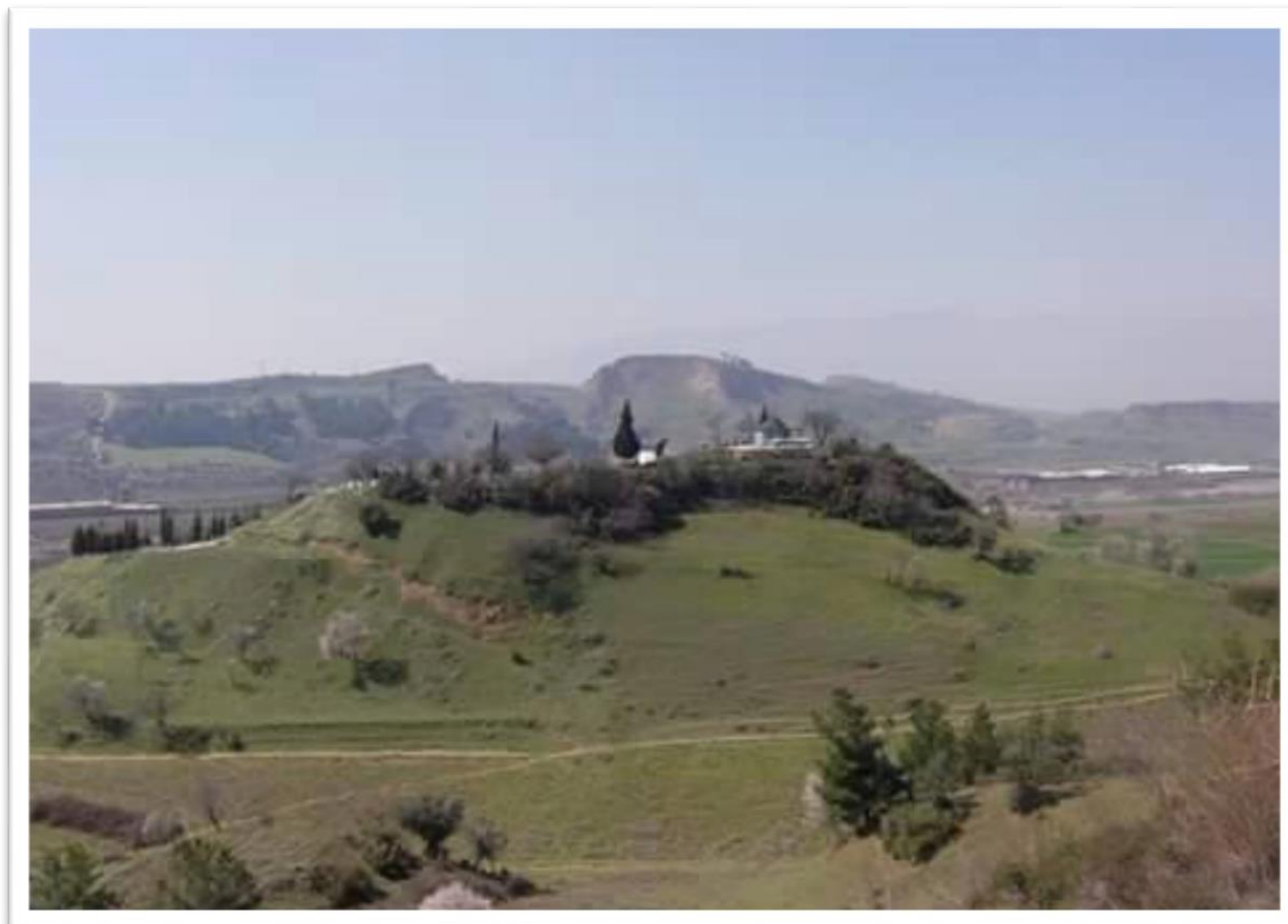

